\title{
Espécies de partidos políticos: uma nova tipologia'
}

\section{Richard Gunther \\ Larry Diamond}

\section{Resumo}

Embora a literatura específica já inclua um grande número de tipologias de partidos, é cada vez mais difícil dar conta da grande diversidade de tipos de partido político surgidos em todo o mundo nas últimas décadas, especialmente porque a maioria das tipologias baseou-se em partidos da Europa Ocidental, já existentes entre o final do século XIX e a metade do século $X X$. Alguns novos tipos evoluíram, mas de maneira fortuita e com base em critérios muito variáveis e frequentemente inconsistentes. Este artigo é uma tentativa de encaixar muitas das concepções de partido comumente utilizadas em uma estrutura coerente e de delinear novos tipos de agremiação partidária sempre que os modelos existentes se mostrarem incapazes de apreender aspectos importantes das legendas contemporâneas. De acordo com seu "gênero", classificamos cada uma das I5 "espécies" de partido com base em três critérios: I) a natureza da organização partidária (forte/fraca, elitista ou de massa, etc.); 2) a orientação programática do partido (ideológica ou particularista-clientelista, etc.); e 3) o caráter tolerante e pluralista (ou democrático) versus o proto-hegemônico (ou antissistema). Embora falte parcimônia nesta tipologia, acreditamos que ela indique com maior precisão a diversidade de partidos existentes no mundo democrático contemporâneo, sendo mais adequada ao teste de hipóteses e à construção de teorias do que outras.

Palavras-chave: Organização partidária; Programas de partido; Sistemas partidários; Tipos de partido.

\section{Sobre os autores}

Larry Diamond é colaborador sênior na Hoover Institution, coeditor do Journal of Democracy e coeditor do Fórum Internacional de Estudos sobre a Democracia do National Edowment for Democracy. E-mail: diamond@hoover.stanford.edu Richard Gunther é professor de Ciência Política na Ohio State University. E-mail: gunther.1@osu.edu

1. Artigo originalmente publicado em Party Politics, vol. 09, n. 02, pp. 167-199. Tradução de Cristiane Yagasaki e revisão técnica de Bruno Bolognesi. 


\begin{abstract}
While the literature already includes a large number of party typologies, they are increasingly incapable of capturing the great diversity of party types that have emerged worldwide in recent decades, largely because most typologies were based upon West European parties as they existed in the late nineteenth through mid-twentieth centuries. Some new party types have been advanced, but in an ad hoc manner and on the basis of widely varying and often inconsistent criteria. This article is an effort to set many of the commonly used conceptions of parties into a coherent framework, and to delineate new party types whenever the existing models are incapable of capturing important aspects of contemporary parties. We classify each of I5 'species' of party into its proper 'genus' on the basis of three criteria: (I) the nature of the party's organization (thick/thin, elite-based or mass-based, etc.); (2) the programmatic orientation of the party (ideological, particularistic-clientele-oriented, etc.); and (3) tolerant and pluralistic (or democratic) versus proto-hegemonic (or anti-system). While this typology lacks parsimony, we believe that it captures more accurately the diversity of the parties as they exist in the contemporary democratic world, and is more conducive to hypothesistesting and theory-building than others.
\end{abstract}

Keywords: Party organization; Party programmes; Party systems; Party types.

Artigo recebido em 20 de novembro de 200 I; aceito para publicação em 25 de abril de 2002. [datas originais de publicação].

Por quase um século, cientistas políticos desenvolveram tipologias e modelos de partido político numa tentativa de apreender as características essenciais das organizações partidárias, objeto de suas análises. Por consequência, a literatura atual é rica, com várias categorias de tipos de partido, algumas das quais adquiriram a condição de "clássicas", sendo utilizadas há décadas por acadêmicos (ex., Duverger, 1954; Kirchheimer, 1966; Neumann, 1956). Acreditamos, contudo, que os modelos de partido existentes não dão conta adequadamente da ampla variedade de tipos de legenda encontrados no mundo atual e que as várias tipologias, baseadas numa multiplicidade de critérios de definição, não propiciaram uma construção teórica cumulativa. Este artigo, portanto, é uma tentativa de reavaliar as tipologias de partido político prevalecentes, sempre que possível aproveitando os conceitos e a terminologia já bastante disseminados, em alguns casos consolidando e esclarecendo modelos partidários e, em outros, definindo novos tipos. Isso se deve a várias razões. 
Primeiramente, quase todas as tipologias existentes derivaram de estudos de partidos da Europa Ocidental ao longo dos últimos 150 anos. Assim, parte de suas características definidoras é produto desse contexto temporal e geográfico específico. Partidos surgidos mais recentemente, assim como aqueles que atuam em outras partes do mundo, foram substancialmente afetados por contextos sociais e tecnológicos muito diferentes. Isso se verifica especialmente em organizações partidárias de países em desenvolvimento, cujas populações exibem uma considerável diversidade étnica, religiosa e/ou linguística, características em que se basearam com muita frequência os partidos competitivos. Verifica-se esse quadro até mesmo nos Estados Unidos, cujos dois partidos, marcadamente descentralizados, dificilmente se encaixam na maioria das tipologias existentes (ver Beck, 1997).

Do mesmo modo, muitos partidos surgidos no final do século XX têm características notórias que não podem ser apreendidas utilizando tipologias clássicas, desenvolvidas um século atrás. Neste último período de desenvolvimento partidário, a televisão (que não existia na época em que as tipologias clássicas foram formuladas) tornou-se, sem dúvida, o mais importante meio de comunicação política de candidatos e eleitores em quase todas as democracias modernas (ver Gunther e Mughan, 2000). Essa mídia privilegia sistematicamente as figuras pessoais das lideranças partidárias, em detrimento da apresentação de programas ou ideologias, ao mesmo tempo que reduz em muito a utilidade da filiação em massa como veículo de mobilização eleitoral. Ainda no final do século XX, pesquisas de opinião e "grupos focais" foram cada vez mais empregados, facilitando a criação de uma publicidade eleitoral específica, às custas dos princípios ideológicos de longo prazo, compromissos programáticos e interesses do eleitorado. Por fim, características fundamentais, concernentes à cultura de massa e à estrutura social, também foram profundamente alteradas no final do século XX: em muitos países, a extrema desigualdade econômica e a alta relevância política da clivagem de classe diminuíram, enquanto novos conflitos políticos nascidos de valores "pós-materialistas” começaram a afetar as políticas partidárias.

Com a ausência de uma tipologia ampliada e atualizada sobre partidos políticos, o pequeno número de modelos que compõem a maioria das tipologias comumente utilizadas leva a uma excessiva 
"elasticidade do conceito". Categorias inadequadas foram aplicadas a legendas partidárias recém-criadas cujas características diferem notadamente daquelas que formaram a definição original de modelo de partido. Na verdade, isso representa uma tentativa de encaixar quadrados em círculos. Tanto os estudos empíricos quanto as construções teóricas podem ser enfraquecidas por hipóteses infundadas de aspectos comuns (se não uniformes) de partidos que são, na verdade, bastante variados, e pela aplicação inapropriada de rótulos a partidos cujas características organizacional, ideológica e estratégica diferem significantemente do protótipo original. O termo catch-all por exemplo, sofreu frequentemente esse tipo de abuso (ver Puhle, 2002), devido a sua condição de facto de categoria residual que aparenta ser mais flexível e adaptável às circunstâncias contemporâneas do que os primeiros modelos partidários clássicos. Portanto, apesar de reconhecermos que muitas contribuições valiosas dos estudos empíricos sobre as organizações partidárias basearam-se nos modelos tradicionais da Europa Ocidental, acreditamos que o estudo dos partidos em outras regiões do mundo, assim como tentativas de apreender melhor a dinâmica das "novas campanhas políticas" das décadas recentes (ver Pasquino, 2001), seria melhorado consideravelmente por meio de uma reavaliação e ampliação desses modelos.

Um segundo problema das tipologias existentes refere-se ao fato de que, em geral, foram embasadas em uma grande variedade de critérios, e pouco ou nenhum esforço foi feito na tentativa de torná -los mais consistentes e compatíveis entre si. Essas inconsistências, assim como a falta de precisão na definição de certos tipos de partido, prejudicou a pesquisa nessa área, reduzindo-a ao desenvolvimento cumulativo de teorias. Algumas tipologias partem de critérios funcionalistas, nos quais as agremiações se diferenciam por uma raison d'être organizacional ou algum objetivo específico buscado. Sigmund Neumann (1956), por exemplo, faz uma distinção entre "partidos de representação individual" (que articulam as demandas de grupos sociais específicos) e "partidos de integração social" (que têm organizações bem desenvolvidas e fornecem vários serviços a seus membros, envolvendo-os em uma comunidade partidária, em troca de contribuições financeiras e serviços voluntários de membros durante as campanhas eleitorais). Na tipologia de Neumann, os "partidos de integração total" têm objetivos mais ambiciosos de 
tomar o poder e transformar radicalmente as sociedades, exigindo o comprometimento total e a obediência incondicional de seus filiados. Herbert Kitschelt (1989) diferencia os partidos que enfatizam a "lógica da competição eleitoral" daqueles (como o tipo libertário de esquerda, que ele mesmo introduz) que insistem muito mais na "lógica da representação eleitoral". Wolinetz (2002), por sua vez, faz distinção entre partidos que privilegiam a arena eleitoral, propõem políticas públicas ou compõem governos. Já Katz e Mair (1995) desenvolvem uma lógica implicitamente funcionalista ao estabelecer o modelo do "partido cartel", no qual o financiamento público dos partidos e o papel fundamental do Estado induziriam os líderes partidários a conter a competição e buscar, principalmente, a perpetuação de si mesmos no poder a fim de beneficiarem-se desses novos recursos.

Outros esquemas de classificação são organizacionais, distinguindo partidos que possuem estruturas organizacionais enxutas daqueles que desenvolveram grandes infraestruturas e complexas redes de relacionamentos colaborativos com organizações de apoio. A concepção máxima clássica, nesse sentido, foi feita por Maurice Duverger, que aperfeiçoou um esquema de "duas categorias e meia", separando partidos "de quadros” (comumente liderados por indivíduos de condição socioeconômica elevada) de partidos "de massa" (que mobilizam amplos segmentos do eleitorado por meio do desenvolvimento de uma vasta e complexa organização), e mencionando também os partidos "de devotos", mas dispensando-os por serem "muito vagos para constituir uma categoria separada"1. Herbert Kitschelt (1994) propõe um sistema de classificação dividido em quatro partes, no qual distingue "agremiações centralistas", partidos "de quadros leninistas", "agremiações descentralizadas" e partidos “descentralizados de massa”. E Angelo Panebianco (1988), por sua vez, na articulação mais elaborada de uma tipologia organizacional, contrapõe partidos "de massa burocráticos" a partidos "eleitorais profissionais".

Alguns estudiosos de política partidária baseiam, implícita ou explicitamente, suas análises na noção de que os partidos resultam

1. Duverger (1954, p. 71). Acreditamos que esse seja um tipo de partido distinto (ao qual nos referiremos como o modelo de partido "leninista"), cujo conceito desenvolveremos mais adiante neste artigo. 
de vários grupos sociais cujos interesses devem estar representados por tais legendas. Essa orientação sociológica caracteriza o estudo desenvolvido por Samuel Eldersveld (1964) e por Robert Michels (1915), como aponta Panebianco (1988, p. 3). Finalmente, há alguns destacados acadêmicos que misturam indiscriminadamente esses três grupos de critério, como Otto Kirchheimer (1966), que propõe quatro modelos partidários: partidos burgueses de representação individual; partidos classistas de massa; partidos de massa denominacionais; e partidos do tipo catch-all. Não nos opomos à noção de que muitos critérios diferentes podem ser utilizados para diferenciar os tipos de partido. De fato, utilizamos três critérios como base para o nosso esquema integrativo. No entanto, acreditamos que o teste sistemático de hipóteses e a construção cumulativa de teorias foram prejudicados pela tendência de proponentes das várias tipologias de se referirem à uma e à outra desavisadamente ${ }^{2}$, sem avaliar de forma sistemática as sobreposições e distinções, nem tampouco mencionar os méritos relativos, dos vários esquemas de classificação. ${ }^{3}$ Essa falta de consistência conceitual e terminológica contrasta fortemente com alguns subcampos da ciência política, como a literatura intimamente relacionada a sistemas partidários, dentro da qual surgiu um claro consenso quanto ao significado (e até mesmo indicadores operacionais específicos) de tais conceitos centrais, como "fragmentação", "volatilidade" e "desproporcionalidade".

Algumas dessas tipologias (mas certamente não todas) basearamse na seleção de apenas um critério como base de concepção (seja a estrutura organizacional, seja o principal objetivo organizacional, seja a base social de representação). Esse procedimento estreitou excessivamente o foco da análise, ao passo que a grande diversidade de tipos de legendas não são estudadas sistematicamente. O que se ganha em termos de parcimônia perde-se em termos de habilidade para abarcar teoricamente as variações significativas entre os partidos políticos no mundo. Além disso, muitos estudos sobre esse tema são excessivamente dedutivos, sugerindo desde o princípio que um critério em particular é de suma importância, sem sustentar que as

2. A frase original do texto é: “to 'talk past' one another”. Essa expressão idiomática se refere a duas pessoas que falam sobre coisas diferentes, contudo pensam que estão falando sobre o mesmo objeto ou assunto. N. R.

3. Uma exceção é Ware (1996), que fornece uma visão geral bastante sistemática. 
afirmações devem ser feitas por meio de uma cuidadosa avaliação das evidências pertinentes. Como resultado, alguns desses estudos foram alvo de argumentos reducionistas, nos quais se presume que muitas características estruturais e comportamentais dos partidos se devem a uma variável privilegiada. Duverger (1954), por exemplo, apresenta uma tipologia baseada em organização, embora também reconheça a grande importância do vínculo de classe social existente entre os partidos de quadros e a classe média e a classe alta, e entre os partidos de massa e a classe trabalhadora. Ele explica essa relação argumentando que essas formas de organização são determinadas por vários níveis de recursos e restrições enfrentados pelos fundadores dos partidos em seus esforços para garantir os recursos necessários para custear as atividades.

Acreditamos, assim como Koole (1996), que essa é uma tentativa prematura de construir teorias elaboradas com base em tipologias possivelmente inadequadas. Uma linha mais aberta e, em última análise, produtiva de estudo empírico deve começar por um conjunto de tipos de partido teoricamente mais modesto, mas empiricamente mais abrangente e correto, que reflita de maneira mais condizente as variações reais entre os partidos. Esse esforço é particularmente necessário ao incluir países de fora da Europa Ocidental em uma análise comparativa preliminar. Portanto, aumentaremos o número de tipos de partido, aproveitando sempre que possível os modelos e terminologias previamente desenvolvidos por outros acadêmicos e, ao mesmo tempo, estabelecendo uma certa ordem em alguns dos critérios mais comumente usados para definir as tipologias partidárias. Especificamente, procuramos evitar a tentação comum de introduzir um novo tipo de partido em campos específicos, baseando-nos apenas na conclusão de que um caso particular não pode ser adequadamente explicado pelas tipologias existentes.

Nossa tipologia de partidos fundamenta-se em três critérios. O primeiro envolve a natureza da organização formal do partido. Algumas agremiações são enxutas em termos de organização, enquanto outras desenvolvem extensas bases de filiados em massa com instituições parceiras ou de apoio, engajadas em distintas, porém relacionadas esferas sociais; algumas contam com redes particulares de interação ou intercâmbio pessoal, enquanto outras são abertas e universais quanto à atração de simpatizantes e filiação; há ainda outras que contam fortemente, se não exclusivamente, com técnicas modernas 
de comunicação de massa e ignoram o desenvolvimento de canais primários de comunicação, face a face, ou através de organizações auxiliares. O segundo critério classificatório envolve a natureza dos compromissos programáticos do partido. Alguns partidos têm posições programáticas derivadas de ideologias bem articuladas e arraigadas em filosofias políticas, crenças religiosas ou sentimentos nacionalistas; outros são pragmáticos ou não têm um compromisso ideológico ou programático bem definido; outros, ainda, estão comprometidos com a promoção dos interesses de um grupo étnico, religioso ou socioeconômico em particular, ou com um eleitorado definido geograficamente, em oposição àquelas agremiações heterogêneas, quando não promiscuamente ecléticas em seus apelos eleitorais aos grupos sociais. O terceiro critério envolve a estratégia e as normas comportamentais do partido, especificamente se ele é tolerante e pluralista ou proto-hegemônico em seus objetivos e comportamento: alguns partidos estão completamente comprometidos com regras do jogo democrático, são tolerantes e respeitam seus oponentes, e têm pontos de vista plurais quanto ao governo e à sociedade; outros são pouco leais às normas e instituições democráticas, ou são explicitamente antissistema, o que favorece a substituição da democracia pluralista existente por um regime mais uniformemente comprometido com a realização de seus objetivos programáticos.

Em nossa discussão mais detalhada sobre as legendas típicas de cada modelo partidário, também trataremos de outras duas dimensões da vida partidária consideradas significantes e que já foram extensamente abordadas pela literatura existente sobre o tema. A primeira dimensão da vida partidária é a sociológica, i. e., a natureza da clientela à qual o partido lança seu apelo e os interesses de quem ele pretende defender ou promover. A segunda envolve a dinâmica interna do processo de tomada de decisões do partido, particularmente a natureza e o grau de proeminência do líder partidário, que pode variar de uma figura carismática dominante, em um extremo, a formas mais coletivas de liderança, em outro. Nossa hipótese é que tipos de agremiação (definidos pelos critérios organizacionais, programáticos e estratégicos listados antes) são frequentemente associados a clientelas sociais particulares e/ou a padrões de liderança, mas não de forma determinística, e certamente não a ponto de tais dimensões, sociológica e de liderança, serem incorporadas à definição dos tipos de partido. 
É importante notar que os modelos de partido político que descreveremos a seguir são tipos ideais, no sentido estritamente weberiano do termo. Assim sendo, eles são heuristicamente úteis na medida em que dão indicações facilmente compreensíveis, que ajudarão o leitor a entender claramente conceitos multidimensionais que, de outra forma, seriam complexos. Além disso, esses modelos facilitam a análise, já que servem como base para comparações que abrangem casos reais, ou como desfechos extremos de processos evolutivos que nunca podem ser realmente alcançados. Como em todos os tipos ideais, no entanto, não se deve esperar que os partidos políticos se ajustem completamente a todos os critérios definidores de cada modelo; de modo semelhante, algumas agremiações podem incluir elementos de mais de um tipo ideal. Talvez o mais importante, os partidos individuais podem evoluir com o tempo, de tal forma que provavelmente em uma época podem estar mais próximos de um tipo e, em outra, mudar em direção a outro tipo.

Figura I. Extensão da organização

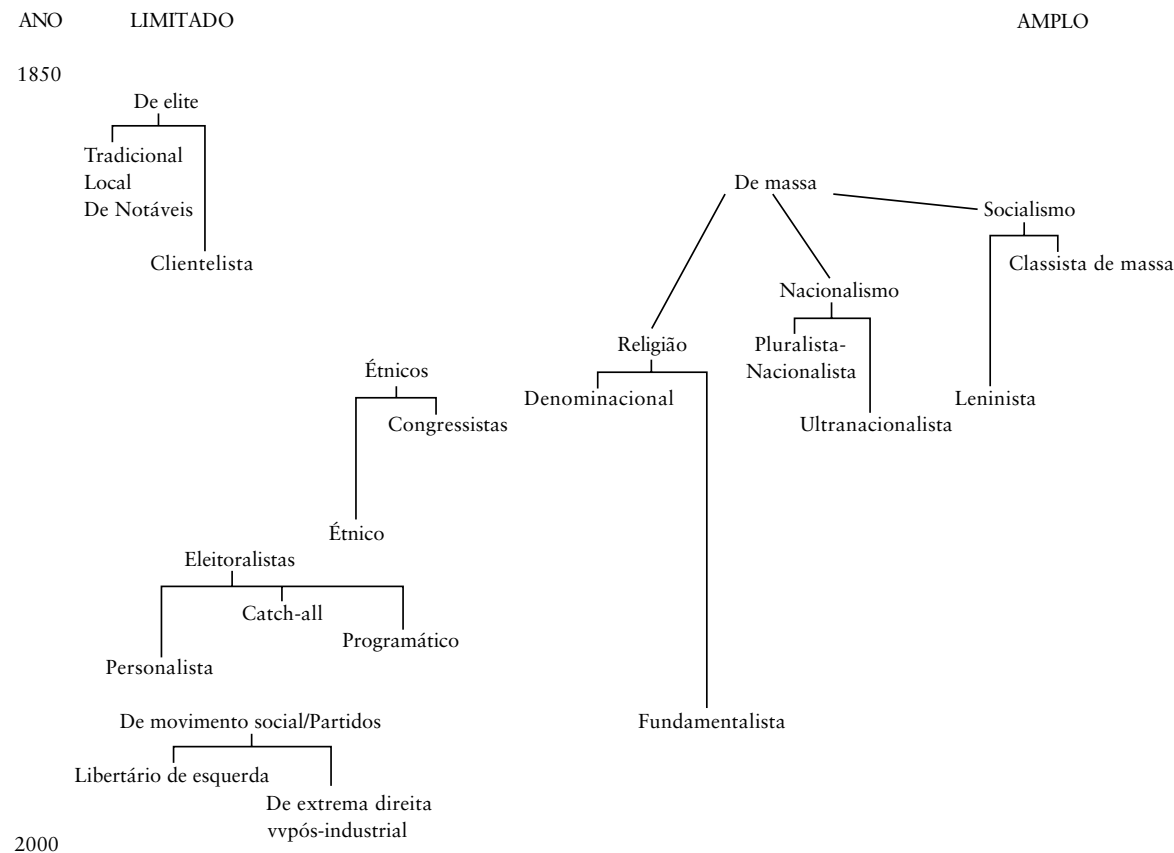




\section{Tipos de partido político}

Com base nesses três critérios, identificamos 15 "espécies" diferentes de partido que acreditamos apreendem melhor a essência básica das agremiações partidárias ao redor do mundo, e durante vários períodos históricos, do que a maioria das tipologias já estabelecidas. No entanto, também reconhecemos uma contrapartida negativa implícita nessa abordagem: a evidente falta de parcimônia pode confundir o leitor ou dificultar a compreensão das diferenças mais cruciais entre os numerosos tipos de legenda. Portanto, privilegiamos uma das nossas três dimensões classificatórias - o tipo de organização do partido. Tomando emprestado uma analogia da biologia, consideramos o tipo de organização do partido tão definidor quanto um gênero, que, por sua vez, abrange várias espécies de partido político. Esses gêneros são: partidos de elite, partidos de massa, partidos étnicos, partidos eleitoralistas e partidos de movimento social. Eles podem ser observados na Figura 1, que mostra esses tipos num esquema de dvaarranjo bidimensional, com partidos "organizacionalmente enxutos" à esquerda e partidos "organizacionalmente amplos" à direita, e com partidos surgidos em períodos históricos anteriores no topo e os mais recentes abaixo.

A correlação entre a extensão organizacional do partido (o quanto é enxuto/amplo) e sua dimensão temporal não é acidental. Um partido político passa a existir dentro de um contexto social e tecnológico específico, que pode evoluir com o tempo, e esse "contexto fundador" pode deixar uma marca indelével por décadas na natureza básica de sua organização. Partidos são canais de intermediação entre as elites políticas e os eleitores, e a capacidade de um tipo específico de organização para mobilizar de maneira efetiva os eleitores é altamente dependente desse contexto. Como defendemos, no século XIX, na maioria dos países da Europa Ocidental (especialmente no Sul), e, no século XX, na maioria dos países da América Latina, camponeses "politicamente imobilizados", muitos dos quais analfabetos e moradores de zonas rurais isoladas, compunham uma grande parte do segmento de eleitores. Nesses setores sociais, as elites tradicionais ou os "notáveis locais" exerciam uma influência considerável e, consequentemente, surgiam partidos de elite organizacionalmente enxutos. Algumas décadas mais tarde, a urbanização, a industrialização, a mobilização política 
da classe trabalhadora e a expansão do direito ao voto exigiram o desenvolvimento de diferentes tipos de agremiação partidária. A mobilização eleitoral destes recém emancipados eleitores foi mais efetivamente empreendida por partidos com grandes bases de filiados e uma extensa infraestrutura organizacional. No entanto, nas quatro últimas décadas do século XX, o advento da televisão possibilitou que as elites políticas se comunicassem diretamente com o eleitorado, e as organizações partidárias de massa começaram a ser relativamente menos eficazes como principal veículo de mobilização eleitoral. Ao mesmo tempo, a secularização e a diminuição da filiação sindical em vários países diminuíram muitas das organizações de apoio, parceiras com as quais os partidos de massa clássicos tanto contaram. Em suma, é possível desenvolver o argumento de que o contexto social/tecnológico no qual os partidos funcionam tem uma influência direta sobre a eficácia dos diferentes tipos de organização partidária, e que as características dominantes desse contexto irão evoluir sistematicamente com o tempo. Isso ajuda a explicar tanto o surgimento dos partidos de massa e o declínio dos partidos de elite no início do século XX, quanto a subsequente substituição das agremiações de massa pelos partidos de organização enxuta como o tipo organizacional dominante ao fim do século. Tal argumento também é perfeitamente cabível em estudos empíricos que mostram que, nos últimos anos, a adesão a partidos políticos vem diminuindo na maioria das democracias estáveis (ver Mair e van Biezen, 2001).

Essa relação geral entre a dimensão histórica e o aparecimento de diferentes tipos de organização de partido não implica, no entanto, que estejamos afirmando ou sugerindo que um tipo de legenda era, é ou será dominante em qualquer período da história. Na verdade, nos surpreendemos com a persistência e diversidade dos partidos hoje existentes, ainda que muitas das circunstâncias sociais ou culturais que a princípio os geraram já tenham desaparecido há muito tempo. Também não queremos afirmar que seja provável que um tipo de partido siga uma trajetória previsível, evoluindo para outro tipo. Por dois motivos: primeiro, uma vez que um partido seja institucionalizado de acordo com um tipo organizacional específico, a natureza básica de sua estrutura organizacional pode ser "congelada" e, portanto, resistir a pressões por mudanças. Desse modo, as agremiações fundadas por notáveis locais eram 
politicamente poderosas (como o Partido Liberal Democrático do Japão) e poderiam permanecer sob o domínio de facções da elite bem depois de a maioria dos eleitores ter deixado de ser reverente à elite dos líderes; de forma similar, os partidos podem manter grandes bases de filiados em massa e vínculos institucionalizados com organizações de apoio, mesmo depois de o partido ter adotado uma estratégia predominantemente eleitoral do tipo catch-all e um processo de tomada de decisões interno deste tipo (p. ex., o Partido Social Democrata Alemão sob a liderança de Gerhard Schröder ou o Partido Trabalhista do Reino Unido comandado sob a liderança de Tony Blair). Segundo motivo, quando o contexto social/tecnológico pode evoluir sistematicamente com o tempo (levando em conta as tendências gerais das últimas décadas, que caminham de partidos com grande extensão organizacional para aqueles nos quais foram observadas bases organizacionais menos desenvolvidas), a relação entre as mudanças sociais ou tecnológicas e as motivações programáticas ou estratégicas dos líderes partidários é muito mais tênue ou não existente. Apresentaremos uma discussão mais extensa dessa indeterminação no final deste artigo.

Em relação às espécies individuais que constituem o gênero mais amplo, deve-se notar que, sempre que possível, o nome que escolhemos para cada tipo de partido veio da literatura existente: isso é verificável para o partido classista de massa, o denominacional e o catch-all, de Kirchheimer; para o libertário de esquerda, de Kitschelt; para o de movimento de extrema-direita pós-industrial, de Ignazi; e para o programático de Wolinetz. Em outros casos, ou nomeamos um tipo de partido que está implícito em um grande corpus da literatura (como o partido de notáveis locais tradicional e o clientelista), ou renomeamos e desenvolvemos mais plenamente o modelo de partido, como o leninista (ao qual Duverger se refere como partido "de devotos"), o étnico (o "partido sociocultural particularista", na terminologia de Kitschelt) e o personalista (chamado por Ignazi de o "partido não partidário"). Em um caso que vale destacar, descobrimos que um rótulo de tipo partidário comumente usado referia-se, na verdade, a um gênero particular: o "partido profissional eleitoral" de Panebianco, que corresponde, grosso modo, ao nosso gênero de partido eleitoralista e sobre o qual delineamos três "espécies" mais específicas de tipos partidários. Por fim, algumas agremiações simplesmente não se encaixaram nesse esquema tipológico (como o 
partido cartel ${ }^{4}$ ), e alguns tipos (o fundamentalista religioso, o étnico e o nacionalista) não têm uma clara definição conceitual preestabelecida na literatura.

\section{Partidos de elites}

Partidos "de elites" são aqueles cujas principais estruturas organizacionais são mínimas e originadas nas elites estabelecidas e redes interpessoais afins em uma área geográfica específica. O reconhecimento da autoridade dessas elites por parte do eleitorado é uma característica compartilhada pelas duas espécies de partido que se encaixam nesse "gênero". Qualquer estrutura partidária de nível nacional fundamenta-se na aliança entre as elites locais. Em termos programáticos, tais agremiações não são ideológicas. No nível mais baixo dentro do partido (isto é, na articulação entre os eleitores e os candidatos locais), o principal compromisso eleitoral envolve a distribuição de benefícios exclusivos aos moradores de uma zona eleitoral geograficamente definida ou aos "clientes" que compõem a base de uma hierarquia patronal-clientelista. Tais partidos não ambicionam ser hegemônicos, e são tolerantes e colaborativos uns com os outros em um regime parlamentar (mas não necessariamente democrático)..$^{5}$

Historicamente (ver Chambers e Burnham, 1967; Daalder, 2001; Katz e Mair, 2002; LaPalombara e Weiner, 1966), o primeiro tipo de partido a surgir foi o que chamamos partido tradicional de notáveis locais. Esse surgimento ocorreu em meados do século XIX, época em que o voto era acentuadamente limitado em regimes semidemocráticos. Levando em consideração que na maioria desses países o direito de voto e de ocupação de cargos eletivos era restrito a homens que

4. De acordo com a convincente argumentação de Koole (1996), a descrição de partido-cartel feita por Katz e Mair (1995) é imprecisa, sendo mais apropriada como descrição da dinâmica de um sistema partidário (isto é, considerando padrões de interação entre partidos) do que de partidos individuais. Se fôssemos incluir o partido cartel em nossa tipologia, o agruparíamos aos partidos eleitoralistas.

5. No que talvez seja o exemplo mais extremo dessa colaboração, o Turno Pacífico, da Espanha do final do século XIX, os dois partidos dominantes se alternavam no poder, conforme acordos pré-eleitorais, a fim de compartilhar de forma mais equitativa a patronagem do governo ao longo do tempo (Martínez Cuadrado, 1969; Tusell, 1976). 
possuíam grandes propriedades, esse jogo competitivo limitava-se às altas classes socioeconômicas. $\mathrm{E}$, considerando que a eleição para cargos públicos requeria apelos a um pequeno número de eleitores emancipados, as campanhas não precisavam de uma organização bem elaborada. Os notáveis locais podiam contar frequentemente com seu prestígio tradicional ou suas relações pessoais com um reduzido e socialmente homogêneo círculo de eleitores para assegurar seus cargos. As burocracias partidárias centrais não existiam, e as organizações de "partidos" nacionais consistiam em alianças relativamente livres ou confrarias que uniam os membros eleitos do parlamento por meio de interesses comuns ou laços de respeito mútuo. As facções parlamentares que dominavam a Câmara dos Comuns Britânica na primeira metade do século XIX, os partidos conservadores franceses no século XIX e início do XX e os vários partidos conservadores contemporâneos do Brasil são exemplos dessa variedade de partido de elite. A expansão do direito de voto e a modernização socioeconômica (que implicavam a mobilização política de setores da sociedade antes excluídos) limitou progressivamente a efetividade eleitoral de partidos tão pouco institucionalizados e pobres em recursos, enquanto a urbanização tornou os partidos de notáveis ruralistas tradicionais cada vez mais irrelevantes para o eleitorado.

O partido clientelista começou a surgir assim que o partido local tradicional se viu diante dos desafios dos segmentos recém-emancipados do eleitorado nas sociedades que estavam passando pelos processos de industrialização e urbanização ${ }^{6}$. De fato, é razoável levantar a hipótese de que o surgimento do partido clientelista foi uma resposta direta das elites locais aos desafios apresentados pela mobilização política das populações anteriormente subjulgadas: assim que o respeito tradicional às elites locais começou a desaparecer, a mobilização eleitoral passou a contar cada vez mais com a troca de favores ou a coerção aberta. O partido clientelista, como o definimos, é uma confederação de lideranças (tradicionais, os recémsurgidos profissionais liberais ou a elite econômica), cada um com sua própria base de apoio (geográfica, funcional ou pessoal), organizada internamente como facções particularistas. Normalmente, esse tipo de agremiação partidária tem uma organização fraca e pouco

6. Katz e Mair (2002) estabeleceram uma distinção similar entre dois tipos de partido de elite. 
ou nenhum foco programático ou ideológico. Sua função principal é coordenar os esforços das campanhas individuais dos líderes, geralmente de forma indireta ou descompromissada, para garantir o poder em nível nacional. As atividades de campanha, por sua vez, baseiam-se em cadeias hierárquicas de relações interpessoais de uma variedade semifeudal, nas quais os padrões arraigados de lealdade estão ligados à troca de serviços e obrigações.

Embora todo partido clientelista se caracterize por uma organização faccionária particularista, em seu apogeu, entre o final do século XIX e início do XX - na Europa Ocidental (uma descrição clássica é de Carr, 1966, capítulo 9), na América Latina (Hagopian, 1996) e nas máquinas partidárias das grandes cidades da América do Norte e na política ruralista do sul desse país (Beck, 1997, 73-7; Gosnell, 1939; Key, 1949) -, a troca de favores pessoais também serviu como principal ferramenta para a mobilização eleitoral das massas. Tais relações são mais comuns em sociedades rurais pré-modernas: em condições de isolamento geográfico longe do centro de governo dominante, juntamente com os altos índices de analfabetismo funcional e a precariedade dos meios de transporte e comunicação, uma relação patrão-cliente pode ser mutuamente benéfica para ambos ${ }^{7}$. Nos Estados Unidos, essa variedade de política estava voltada para as populações de imigrantes carentes de recursos políticos, e até mesmo de algumas habilidades básicas (como o domínio da língua inglesa) ou das conexões pessoais necessárias para prosperar economicamente (ver Erie, 1988). Com o avanço da modernização socioeconômica - como as decrescentes populações rurais, que se tornam cada vez mais alfabetizadas, expostas aos meios de comunicação de massa e politicamente "mobilizadas" (ou como as populações de imigrantes nos Estados Unidos que aprenderam inglês e se tornaram educadas e adaptadas à sociedade norte-americana) -, a utilidade do patroneio para o cidadão diminui, e as tentativas do

7. Como um funcionário de um partido de uma região rural e socioeconomicamente atrasada da Espanha descreveu: "O cidadão que está preocupado em resolver um problema com o médico ou com a escola [...], ou um problema como uma acusação injusta no tribunal, ou de inadimplência para pagar os impostos devidos ao Estado, etc., [...] recorre a um intermediário [...] que pode interceder por ele, mas em troca da garantia de sua própria consciência e de seu voto." (Gunther et al., 1986, p. 84-85). 
patrão em influenciar as decisões eleitorais encontram resistência. Nessas circunstâncias, as formas mais coercivas de intercâmbio patrão-cliente tendem a emergir, envolvendo frequentemente a ameaça de reter os benefícios econômicos do cliente a não ser que este se comprometa a dar seu apoio político, ou a substituição da troca de favores pela ostensiva compra de votos. No longo prazo, porém, a modernização socioeconômica e a frequente "mobilização cognitiva" do público em geral reduziram em muito a utilidade do clientelismo como veículo de mobilização eleitoral (ver Huntington e Nelson, 1976, p. 7-10 e p. 125-130).

Todavia, uma vez institucionalizadas e incorporadas à estrutura dos partidos políticos, essas relações clientelísticas podem ganhar vida própria, independente das condições socioeconômicas que as originaram. Na Itália e no Japão, cujos sistemas partidários no pós-guerra foram estabelecidos em sociedades menos modernizadas (particularmente no sul da Itália e nas zonas rurais do Japão), o clientelismo consolidou-se na própria estrutura dos partidos dominantes (o Partido Democrata Cristão e o Partido Liberal Democrático, respectivamente). Uma vez estabelecidas, essas redes faccionárias se tornaram as principais bases do recrutamento da elite nesses partidos governantes de ambos os sistemas, e continuaram a existir mesmo após o desaparecimento das condições socioeconômicas que as originaram. Apesar de essas organizações terem sobrevivido por décadas, é interessante notar que as relações clientelistas nas quais essas redes se baseiam podem conter as sementes de sua própria ruína final. $\mathrm{O}$ particularismo e a distribuição de recompensas por adesão faccionária facilmente evoluem para a corrupção ostensiva. Não é de admirar que partidos clientelistas de ambos os sistemas sofreram sérios - e, no caso dos partidos italianos, fatais - retrocessos eleitorais como parte da reação popular a escândalos de corrupção. ( $\mathrm{O}$ mesmo aconteceu recentemente na Tailândia e nas Filipinas, embora alguns partidos desses países mantenham características do modelo clientelista). Com as mudanças sociais, esses tipos de relação se tornaram cada vez mais repugnantes a grandes parcelas do eleitorado, e, quando os diversos escândalos vieram à tona, uma série de defecções nos outrora partidos governantes dominantes minou drasticamente sua unidade e força organizacional. 


\section{Partidos de massa}

O segundo gênero de agremiação partidária tem profundas raízes na literatura, assim como na história europeia do século XIX e início do XX. O “partido de origem externa” por excelência, o partido de massa, surgiu como manifestação da mobilização política da classe trabalhadora em muitos regimes europeus ${ }^{8}$. Em termos de organização, esse gênero se caracteriza por uma ampla base de membros contribuintes que permanecem ativos nos assuntos do partido mesmo em períodos não eleitorais. No intuito de disseminar a ideologia do partido e estabelecer uma base ativa de filiados, a agremiação de massa busca penetração nas diversas esferas da vida social. Organizações auxiliares (sindicatos, associações religiosas, e outras organizações sociais) servem não apenas como aliados políticos (ajudando a mobilizar adeptos durante a campanha eleitoral), mas também para projetar os objetivos programáticos do partido para extrapolando a arena eleitoral-parlamentar para as várias esferas da vida social. É estabelecido um vasto conjunto de organizações de apoio, inclusive jornais do partido e clubes recreativos, e redes compostas pelas alas locais do partido são fundadas por toda a nação. Essas redes organizacionais não apenas servem de moldura para a mobilização durante a campanha eleitoral, como também fornecem benefícios adicionais aos membros do partido, como oportunidades de confraternização e recreação (ver Barnes, 1967).

Dois tipos de distinção dividem esse gênero em seis diferentes espécies partidárias. O primeiro envolve a diretriz básica dos compromissos programáticos, da ideologia e/ou do sistema unificador de crenças do partido. Frequentemente, implicam diversos tipos de compromisso para 1) o socialismo, 2) o nacionalismo ou 3) a religião. A segunda dimensão diz respeito ao grau de tolerância ou pluralismo de cada um deles, por um lado, ou de seu empenho em assegurar uma posição hegemônica no sistema político e impor seus

8. Deve-se notar que alguns partidos camponeses têm muitos aspectos em comum com os partidos de massa da classe trabalhadora, incluindo características organizacionais e origens históricas similares. Vamos nos ater aqui à variante mais difundida do partido de massa - a da classe trabalhadora -, que fornece uma mostra mais abrangente das diversas características desse modelo. 
compromissos programáticos radicais à sociedade, por outro. Os partidos pluralistas partem do pressuposto de que estarão sempre funcionando dentro de um sistema democrático; portanto, aceitam suas instituições e regras. Já os partidos proto-hegemônicos ambicionam, no longo prazo, substituir as sociedades pluralistas e o sistema democrático existentes por um sistema mais condizente com o cumprimento de seus objetivos de transformação radical. Por isso, aceitam as instituições e as regras existentes apenas porque lhes é oportuno e por não poderem ser substituídas a curto prazo, e seu comportamento é, na melhor das hipóteses, semileal (ver Linz, 1978, p. 28-45).

Partidos de massa pluralistas procuram ganhar eleições como sua principal via de acesso à conquista de seus objetivos programáticos, e suas estratégias de mobilização de votos muito dependem do desenvolvimento e da ativação de uma base de filiação em massa. Os militantes do partido desempenham diferentes tarefas, desde o proselitismo e a distribuição de propaganda impressa até acompanhar os eleitores às urnas. As organizações de apoio aliadas ao partido (sindicatos, grupos religiosos e/ou organizações sociais) incentivam seus membros a apoiar o partido, e, se este é bem-sucedido em estabelecer seus próprios meios de comunicação, seu jornal e/ou programas de rádio e TV ficam abarrotados de mensagens partidárias. Embora se requeira certa ressocialização dos novos membros, o recrutamento de militantes para o partido é aberto.

Em contrapartida, as agremiações de massa proto-hegemônicas enfatizam bastante a disciplina, o permanente e ativo engajamento e lealdade por parte dos membros na condução do confronto político nas arenas eleitorais e extraparlamentares. Portanto, o recrutamento de membros é muito seletivo; a doutrinação, intensiva; e a aceitação da ideologia e da linha de pensamento, obrigatória a todos os membros. Em alguns casos (particularmente quando os partidos proto -hegemônicos estavam na clandestinidade), adota-se uma estrutura celular, secreta e conspiratória, oposta à organização em correntes abertas que caracteriza os partidos de massa pluralistas. No geral, a distinção entre partidos de massa pluralistas e proto-hegemônicos aproxima-se da diferenciação de Duverger entre partidos de massa de correntes e partidos de devotos organizados em células (1954, p. 63-71), e também a divisão de Neumann (1956) entre partidos de “integração social” e de "integração total”. 
As organizações partidárias com compromissos ideológicos socialistas, ou ganharam a forma de partidos sociais-democratas classistas de massa ${ }^{9}$, ou adotaram a postura proto-hegemônica dos partidos "leninistas". No partido de massa típico (para utilizar a terminologia de Kirchheimer, 1966), o centro de poder e autoridade localiza-se no comitê executivo de seu secretariado, embora, formalmente, a principal fonte legítima de autoridade seja o congresso geraldo partido. Além disso, a liderança parlamentar do partido ocasionalmente entra em confronto com o secretariado pelo controle da agenda programática e pela nomeação de candidatos. Invariavelmente, a postura aberta e tolerante desses partidos possibilitou consideráveis conflitos internos, especialmente entre os pragmáticos, cuja principal preocupação é a vitória nas urnas, e os ideólogos, que valorizam muito mais a "representação do eleitorado" e a consistência ideológica, com uma leitura mais ortodoxa da ideologia partidária (ver Michels, 1915). Em alguns casos, tal confronto pode levar à divisão do partido em duas organizações independentes (como o antigo Partido Socialista Democrático Italiano e o Partido Socialista Italiano da "Primeira República” da Itália). Esse quadro tem culminado, mais comumente, na gradual conversão dos partidos socialistas maximalistas em partidos mais moderados e pragmáticos.

Os partidos classistas de massa estabelecem bases entre seus eleitores de classe por meio de grupos organizados tanto geograficamente (comitês locais) quanto funcionalmente (os sindicatos). Embora busquem fazer proselitismo com possíveis membros ou eleitores, a doutrinação e a exigência de conformidade ideológica são mínimas. Apesar de a integração social por meio das atividades partidárias e dos sindicatos aliados ser um objetivo significativo, o partido está mais preocupado em ganhar as eleições e participar da formação de governos. O recrutamento de membros é bastante aberto, e, quanto maior for a base do partido, tanto melhor, considerando sua principal preocupação, que é garantir a maioria dos votos, e sua tradicional dependência da capacidade de seus membros para mobilizar o eleitorado. Os partidos socialdemocratas da Alemanha, Suécia e Chile são bons exemplos desse tipo de agremiação.

9. Para excelentes descrições e análises desse tipo de partido, ver Barnes (1967) e Epstein (1967, capítulo 6, "O Partido Socialista do Proletariado”). 
Os partidos leninistas (como os definimos, baseando-nos na ideologia e na proto-hegemonia de classes) têm como objetivo a derrubada dos sistemas políticos existentes e a implantação de mudanças revolucionárias na sociedade. Considerando que seus objetivos revolucionários provavelmente sofrerão vigorosa resistência, quando não reprimidos por seus opositores, o partido adota uma estrutura fechada, com base na célula semi-secreta (ao invés de comitês abertos, que caracterizam os partidos de massa pluralistas). A filiação é altamente secreta, e o partido exige lealdade e obediência estritas por parte dos membros, exercendo uma intensa e intransigente doutrinação ideológica sobre eles. O partido tem penetração em setores fundamentais da sociedade (especialmente nos sindicatos e na classe média intelectual dos países ocidentais, e na classe camponesa da Ásia), no intuito de assegurar aliados táticos, no curto prazo, e a conversão, no longo prazo. Internamente, o processo de tomada de decisões é bastante centralizado e autoritário, mesmo que o centralismo democrático frequentemente permita o debate aberto antes do anúncio de uma decisão oficial. $\mathrm{O}$ partido vê a si mesmo como a "vanguarda" do proletariado, e, apesar de se autorretratar como representante da classe trabalhadora, desempenha um papel de liderança explicitamente direcionador e de cima para baixo para com a classe que representa, definindo seus interesses. Embora a postura inicial dos partidos leninistas prototípicos (os pertencentes ao Komintern ${ }^{10}$ ) seja a de rejeitar as instituições e parlamentos representativos da "burguesia", a maioria dos partidos comunistas participou como competidores antissistema e semileais da política eleitoral nas democracias ocidentais. O principal objetivo do partido é conquistar o poder, mesmo que à força. Nas democracias ocidentais, as agremiações originalmente leninistas, ou passaram por transformações graduais - geralmente se tornando partidos de massa pluralistas -, ou sofreram cisões, dividindo-se em partidos democráticos moderados (como o italiano Partido Democrático da Esquerda (PDS), hoje Democratas da Esquerda) e partidos mais ortodoxos (como o Rifondazione ${ }^{11}$ ).

Se o partido leninista consegue chegar ao poder (como foi o caso na Europa Central e do Leste e em partes da Ásia), modifica seu

10. Termo que referencia a Internacional Comunista a partir de Lênin. N. R. 11. Refundação Comunista, partido italiano da esquerda europeia. N.R. 
papel autodeterminado e seu comportamento em relação a outros grupos sociais e políticos. O partido vê a si mesmo como a "expressão organizada da vontade da sociedade”. Na ex-União Soviética, ele "é a expressão 'dos interesses de uma nação inteira'; para os chineses, representa 'os interesses do povo'” (Schurmann, 1966, p.100). Como tal, estabelece o controle hegemônico do sistema político e econômico, abolindo ou assumindo o comando das organizações de apoio estabelecidas, e utilizando praticamente todos os grupos sociais organizados como arenas para a integração social dos indivíduos à nova sociedade que desejam criar. $\mathrm{O}$ partido direcionará as atividades do Estado e presidirá o recrutamento das elites governantes.

Enquanto os partidos leninistas clássicos eram aqueles pertencentes ao Komintern e aceitavam os 21 pontos de Lênin (que diferenciam os partidos comunistas de outros partidos marxistas), alguns partidos não comunistas (como o Kuomintang anterior à democratização de Taiwan ao fim dos anos 1980 e início dos 1990) se adaptaram a muitas dessas características organizacionais e operacionais ${ }^{12}$.

Os partidos nacionalistas pluralistas, como o Partido Nacionalista Basco e, até o fim da década de 1990, o Partido Democrático Progressista de Taiwan, tomaram várias formas. A maioria deles conta com bases de filiação em massa, vasta organização partidária e colaboração com grupos auxiliares secundários que geralmente incluem organizações culturais e, às vezes, sindicatos. A clientela eleitoral desses partidos são aqueles indivíduos que se definem subjetivamente como pertencentes a um grupo nacional distinto. A maioria dessas identidades nacionais se pauta por algumas características sociais (especialmente as que envolvem língua e cultura), e os limites da clientela eleitoral são bastante maleáveis. De fato, uma das principais funções dos partidos nacionalistas é não apenas convencer os cidadãos a votar neles, mas também usar sua campanha eleitoral e as organizações de apoio afiliadas a ele para fomentar e intensificar a identificação com o grupo nacional e suas aspirações. Além disso, tais aspirações envolvem, por definição, uma demanda

12. Por esses aspectos organizacionais, o Kuomintang foi frequentemente classificado como partido "leninista", desde sua fundação no continente chinês, no início do século XX, até sua democratização na década de 1990. Entretanto, no poder, o Kuomintang (no continente e em Taiwan) descartou os aspectos revolucionários de sua ideologia, tornando-se apenas “quase leninista” em sua natureza. 
por certo nível de autogoverno territorial, variando desde a autonomia dentro de um Estado multinacional até a independência total ou a redefinição de fronteiras internacionais em resposta a uma reivindicação insurrentista. Assim, embora possam ser moderados em suas preferências políticas relativas a problemas econômicos, religiosos e muitos outros envolvendo o espectro direita-esquerda, tais partidos podem assumir uma postura semileal ou antissistema em relação a questões de governo territorial. No entanto, frequentemente haverá tensões internas entre aqueles que cobram uma postura mais militante na defesa das reivindicações nacionalistas do grupo e os que valorizam a cooperação com outros partidos na formação de coalizões governamentais, pressionando pela promulgação de uma legislação gradativamente benéfica ao grupo.

Os partidos ultranacionalistas são proto-hegemônicos em suas aspirações. Eles promovem uma ideologia que exalta a nação ou a raça dos indivíduos, é avessa às minorias e admira abertamente o uso da força por um partido forte, quase militar, frequentemente contando com uma milícia uniformizada (ver, p. ex., Orlow, 1969 e 1973). Em alguns aspectos, podem ter muitos arranjos organizacionais e comportamentais em comum com os partidos leninistas, em especial o processo de recrutamento extremamente seletivo, a intensa doutrinação dos membros, a rigorosa disciplina interna, o objetivo imperioso de dominação (por meio da força, se necessário) e a postura antissistema ou semileal no parlamento. Também como os partidos leninistas, quando os ultranacionalistas chegam ao poder, buscam a dominação hegemônica da política e da sociedade por meio da repressão ou cooptação das organizações auxiliares existentes, juntamente com uma ampla penetração na sociedade, na tentativa de re-socializar todas as pessoas no sentido de apoiarem ativamente o regime. Todavia, diferem dos partidos leninistas não apenas em relação ao seu conteúdo ideológico, mas também porque suas ideologias são menos precisas e sujeitas à reinterpretação por um líder carismático nacional ${ }^{13}$. Além disso, o líder nacional é a fonte derradeira de poder e autoridade, enquanto a burocracia do partido é

13. Como Mussolini certa vez descreveu seus colegas fascistas: "Nós nos damos ao luxo de ser aristocratas e democratas, conservadores e progressistas, reacionários e revolucionários, legitimistas e ilegitimistas, de acordo com as condições de tempo, lugar e circunstância” (apud Schmidt, 1939, p. 97). 
apenas um suporte, quando não servil. São bons exemplos desse tipo de agremiação o partido nazista de Hitler, os fascistas de Mussolini e, mais recentemente, a União Democrática Croata (HDZ) de Franjo Tudjman e a Unidade Nacional Russa de Aleksander Barkashov. A notável frequência com que um chefe carismático domina esse tipo de partido sugere a existência de algo, tanto nas circunstâncias sócio-históricas que dão origem aos partidos ultranacionalistas e fascistas, quanto nas personalidades atraídas para esse tipo de partido (Adorno et al., 1950), que gera devoção intensa e submissa a um líder único e onipotente.

A terceira base programática dos partidos de massa é a religião. Novamente, duas variantes diferentes podem ser identificadas. A primeira é pluralista, democrática e tolerante. A origem do partido de massa denominacional (utilizando mais uma vez a terminologia de Kirchheimer, 1966) pode ser remontada ao final do século XIX (ver Fogarty, 1957; Kalyvas, 1996), mas esse tipo de agremiação atingiu sua máxima importância com as consequências da Segunda Guerra Mundial. Exemplos de legendas denominacionais incluem os numerosos partidos democratas cristãos da Europa Ocidental, que tiveram um importante papel, particularmente desde a Segunda Guerra (na Itália, Alemanha, Bélgica, Holanda, entre outros) e também, mais recentemente, na Polônia e na República T checa, com a Democracia Cristã (ZChM) e a União Democrática Cristã (KDU), respectivamente. Eles têm muitas características organizacionais em comum com os partidos de massa, inclusive a existência de uma base composta de membros contribuintes, uma organização partidária hierarquicamente estruturada ligando os níveis nacional e local, jornais e canais de radiodifusão próprios, o apoio de organizações aliadas (geralmente religiosas, mas, em alguns casos, sindicatos). Contudo, diferem num importante aspecto dos partidos de ideologia secular: como sua base programática é um conjunto de crenças religiosas determinado por uma combinação de tradições e interpretações feitas por clérigos e/ ou instituições religiosas externos ao partido em si, ele não detém o controle total de seus preceitos ideológicos fundamentais quando estes estão estritamente ligados a valores religiosos (como aqueles concernentes ao aborto, ao divórcio, à preferência sexual e a certas manifestações artísticas). Isso pode levar a tensões intrapartidárias toda vez que os líderes decidem modificar os apelos eleitorais ou os compromissos programáticos, de tal forma que os valores entrem 
em conflito. O Partido Democrata Cristão Italiano, por exemplo, teve sérios problemas internos ao tratar da legalização do divórcio, à qual a hierarquia da Igreja Católica se opôs ferrenhamente. As crenças religiosas podem estar sujeitas a interpretações várias, e pode existir uma considerável heterogeneidade nos partidos de massa denominacionais, levando a conflitos.

O último tipo de partido de massa é o religioso proto-hegemônico, ou religioso fundamentalista. A principal diferença entre esse tipo e o partido de massa denominacional é que o primeiro busca reorganizar o Estado e a sociedade com base em uma leitura rígida dos princípios religiosos doutrinários, enquanto os partidos denominacionais são pluralistas e moderados. Para os partidos fundamentalistas, há pouco ou nenhum espaço para interpretações conflituosas das normas e escrituras religiosas que servem de base ao programa partidário e às leis que buscam impor à sociedade. A autoridade dos líderes religiosos na interpretação do texto e na sua tradução coerente, em termos políticos e sociais, é inequivocamente reconhecida. Nesse modelo partidário teocrático não há separação entre religião e Estado, e as normas religiosas são impostas a todos os cidadãos, a despeito de suas crenças religiosas próprias. Considerando os objetivos de longo alcance desses partidos (o que pode os aproximar do totalitarismo), seu desenvolvimento organizacional e o escopo de suas atividades são amplos. Os membros têm um substancial, e até mesmo intenso, envolvimento e identificação com o partido, e as organizações auxiliares firmam presença em nível local por toda a sociedade. Considerando a natureza fundamentalista dessas agremiações e sua leitura rígida dos textos religiosos, as relações de autoridade dentro do partido são hierárquicas, não democráticas e absolutistas, e seus membros disciplinados e dedicados. Os partidos fundamentalistas mobilizam apoio não apenas invocando as doutrinas e a identidade religiosas e propondo políticas derivadas desses princípios, mas também por meio de incentivos seletivos; eles geralmente desempenham uma ampla variedade de funções de bem-estar social que ajudam no recrutamento e na consolidação da lealdade dos membros. Essa rede de atividades e serviços organizados enclausura os membros em uma subcultura própria. Embora não sejam partidos de classe, atraem maciçamente o apoio dos pobres e oprimidos, além da classe média marginalizada, cujas denúncias de injustiças e corrupção repercutem de forma especial. Um exemplo 
desse tipo de organização é a Frente de Salvação Islâmica da Argélia, que tem algumas características em comum com o já banido Partido do Bem-Estar da Turquia.

\section{Partidos étnicos}

Aos partidos que se baseiam em etnias, geralmente falta a organização ampla e elaborada dos partidos de massa. Entretanto, o que mais os distingue é sua lógica política e eleitoral. Diferente da maioria dos partidos de massa, eles não promovem um programa (moderado ou transformador) para toda a sociedade. Seus objetivos e estratégias são mais limitados: promover os interesses de um grupo étnico em particular ou de uma aliança de grupos. E, diferente de partidos nacionalistas, seus objetivos programáticos normalmente não incluem dissidências nem uma esfera centralizadade tomada de decisões e de autonomia administrativa do Estado. Ao contrário disso, se contentam com a utilização das estruturas disponíveis do Estado para canalizar benefícios para sua clientela eleitoral particularista.

O partido puramente étnico procura apenas mobilizar os votos de seu próprio grupo étnico. Exemplos históricos clássicos são o Congresso do Povo Nortista e o Grupo de Ação da Primeira República da Nigéria, e, mais recentemente, o Partido da Liberdade Inkatha da África do Sul, o partido da minoria turca (DPS, Movimento pelos Direitos e Liberdades) na Bulgária, a União Democrática dos Húngaros na Romênia e o (Sikh) Akali Dal no estado indiano do Punjab. Embora possam lançar candidatos em outras circunscrições geográficas ou levantar importantes problemas nacionais e até mesmo ideológicos, isso apenas mascara mal e mal sua verdadeira função étnica (ou regional). Como argumenta Kitschelt (2001), a característica definidora dos partidos étnicos (aos quais ele se refere como "partidos socioculturais particularistas") é a limitação de seu apelo a um eleitorado específico, pois "procuram explicitamente traçar fronteiras" étnicas entre "amigos" e "inimigos". O principal objetivo de um partido étnico não é um programa ou plataforma universalista, e sim a garantia de benefícios (e proteção) materiais, culturais e políticos para o seu grupo étnico em sua competição com outros grupos. Assim sendo, tais agremiações têm níveis extremamente baixos de compromisso e coerência ideológica ou programática. Além disso, em 
geral não possuem uma estrutura organizacional muito desenvolvida nem uma base formal de filiação. Carecendo de qualquer interesse funcional e agenda ideológica, tendem a mobilizar as relações clientelistas preexistentes, tanto que sua estrutura e relações internas de autoridade lembram as dos partidos clientelistas. Pelo fato de colocarem em circulação questões simbólicas de identidade (e até mesmo de sobrevivência cultural) poderosamente emocionais, os partidos étnicos tendem a ser dominados e mesmo organizados em torno de um único líder carismático (como o NPC de Ahmadu Bello, o Grupo de Ação Obafemi Awolowo e o Mangosuthu Buthelezi de Inkatha). A lógica eleitoral do partido étnico é consolidar e mobilizar sua base étnica com apelos exclusivos e frequentemente polarizadores quanto às oportunidades e ameaças do grupo. Diferente de praticamente todos os demais partidos políticos (inclusive os nacionalistas) ${ }^{14}$, a mobilização eleitoral não tem como objetivo atrair outros setores da sociedade para apoiar o partido (ver Horowitz, 1985, p. 294-297), cujos interesses são vistos como em conflito inerente com os de outros grupos étnicos. Portanto, mais do que nos partidos religiosos fundamentalistas, sua clientela eleitoral potencial é estritamente determinada e limitada pela etnia, embora dentro dessa categoria definidora os apelos eleitorais entre as classes possam levar à adoção de objetivos programáticos ecléticos. Como os partidos étnicos são, por definição, incapazes de se expandir significativamente para além de suas bases eleitorais, ficam impossibilitados de buscar a hegemonia, a não ser que atinjam uma maioria demográfica ou anulem a democracia. Por meio de fraudes eleitorais e da manipulação do censo, o NPC da Nigéria conseguiu a dominação etnorregional durante a Primeira República. A busca por tal dominação por um partido étnico pode levar a violentos conflitos e foi, efetivamente, um fator que contribuiu para a guerra civil nigeriana.

Um partido congressista é uma coligação, aliança ou federação de partidos ou máquinas políticas, embora possa tomar a forma

14. Esse é o fator principal que distingue os partidos étnicos dos nacionalistas. Esse último busca expandir sua base eleitoral convencendo um número cada vez maior de cidadãos de que devem se identificar com o grupo nacional e sua missão, e frequentemente define "nação" de forma flexível, para facilitar seu objetivo. O partido étnico considera as fronteiras do grupo definidas demograficamente como "dadas" e busca representar exclusivamente seus interesses. 
estrutural de um só partido unificado. Por isso, em nível local, pode compartilhar algumas características organizacionais e compromissos programáticos com os partidos étnicos (como a distribuição de benefícios a um vasto conjunto de redes patrono-cliente); entretanto, dentro do sistema político nacional, o partido se comporta de forma drasticamente diferente. Seu apelo eleitoral é pela unidade e integração, ao invés da divisão nacional; pelo compartilhamento e coexistência, e não pela dominação e ameaça étnicas. Enquanto um sistema consociativo procura dividir o poder e os recursos e garantir a segurança mútua entre os grupos da coligação governamental formada após as eleições, um partido congressista constrói as garantias da coligação com antecedência, dentro do amplo arco de sua organização partidária. Se o arco construído for amplo o suficiente, o partido pode se tornar dominante, como o arquétipo deste modelo, o Partido Congressista que atuou na Índia durante suas primeiras duas décadas de independência. Exemplos menos democráticos são a União Nacional Africana do Quênia, sob a liderança de Jomo Kenyatta, e o Barisan Nasional (coligação da Frente Nacional) da Malásia. Se a envergadura do arco multiétnico é incompleta, o partido congressista pode ser apenas o primeiro entre outros semelhantes, como aconteceu com o Partido Nacional da Nigéria, durante a Segunda República (1979-1983), e com o atual partido governista nigeriano, o Democrático Popular. Em ambos os casos, o partido congressista aloca os postos partidários e cargos do governo e distribui patrocínios e outros benefícios, de acordo com a proporção ou outras fórmulas quase consociativas. Sua base social é ampla e heterogênea, e seu objetivoo é torná-la tão inclusiva quanto possível. Entretanto, sua própria amplitude o torna vulnerável a cisões ao longo das linhas divisórias étnicas ou regionais.

\section{Partidos eleitoralistas}

Há três tipos de partido no gênero mais abrangente de "partidos eleitoralistas”, com características fundamentais similares àquelas utilizadas por Panebianco (1988) no desenvolvimento de seu conceito de "partido eleitoral-profissional" 15 . Os partidos pertencentes a esse

15. Panebianco (1988, p. 264) resumiu as características dominantes dos partidos eleitorais- profissionais como: 1) papel central de profissionais especializados 
gênero são organizacionalmente enxutos e mantêm uma estrutura relativamente limitada (apenas com os e funcionários auxiliando seus respectivos grupos parlamentares). Entretanto, em tempos de eleição, esses partidos entram em ação para conduzir a campanha, o que, inequivocamente, é sua função precípua. Utilizam técnicas "modernas" na campanha (enfatizando a televisão e outros meios de comunicação de massa, em vez da mobilização dos membros do partido e das organizações afiliadas), e contam pesadamente com profissionais que podem conduzir com competência essas campanhas (Farrell et al., 2000). A reputação pessoal de seus candidatos é um critério importante para a indicação, em detrimento de outras considerações, como o tempo de serviços prestados ou a posição formal na organização do partido. No entanto, resistimos à tentação de considerar os partidos eleitoralistas como de tipo único, já que diferem em alguns importantes aspectos que afetam de forma significativa seu comportamento e, consequentemente, a qualidade da democracia. Em consonância com isso, estabelecemos três tipos ideais de partido que se encaixam nesse gênero. Esses três tipos têm as mesmas características organizacionais descritas acima, mas se diferenciam nas outras duas dimensões classificatórias: a dois deles falta o forte compromisso ideológico e programático, enquanto o outro tipo busca desenvolver um conjunto distinto de programas; dois são certamente pluralistas, enquanto o terceiro pode ter ou não ambições hegemônicas.

O primeiro é o partido catch-all ${ }^{16}$. Esse tipo ideal de partido pluralista e tolerante se distingue sobretudo por uma organização elementar, uma ideologia vaga e superficial e uma orientação

em mobilização eleitoral; 2) laços verticais fracos com grupos sociais e apelos maiores à "opinião do eleitorado"; 3) proeminência de representantes públicos e lideranças personalizadas entre seus quadros; 4) financiamento por meio de grupos interessados e fundos públicos (em oposição à antiga dependência das contribuições dos membros); e 5) ênfase em resultados e liderança.

16. Assim como Wolinetz, desmembramos o partido catch-all de Kirchheimer em dois tipos distintos, baseando-nos em seus diferentes níveis de compromisso com uma ideologia ou com um conjunto estável de resoluções programáticas. Wolinetz (1991, p. 118) se refere ao que chamamos de partido catch-all como partido "de resultados/ oportunista". Compartilhamos seu uso do termo "partido programático" (1991) para nos referirmos aos partidos eleitoralistas organizacionalmente enxutos, cujos compromissos ideológicos ou programáticos são razoavelmente fortes. 
predominantemente eleitoral, bem como pela a liderança proeminente e pelo papel eleitoral dos principais candidatos nacionais. $\mathrm{O}$ propósito primordial (se não único) dos partidos do tipo catch-all é maximizar o número de votos, ganhar as eleições e governar. Para tanto, buscam agregar a maior variedade possível de interesses sociais. Nas sociedades em que a opinião pública se distribui (num espectro direita-esquerda) de modo unimodal e centrista, tais partidos procuram obter o maior número de votos posicionando-se no centro do espectro, revelando-se moderados em suas preferências políticas e comportamentais. No intuito de estender seu apelo eleitoral a vários grupos, suas orientações políticas são ecléticas e mudam conforme o humor do público. Não possuindo uma ideologia explícita, o partido catch-all tende a enfatizar os atributos de atratividade pessoal de seus candidatos, e as indicações são na maior parte determinadas pelos recursos eleitorais dos candidatos, e não por critérios organizacionais, como anos de experiência ou de serviço ao partido, ou posição dentro das alas principais do partido. O Partido Democrata dos Estados Unidos, o Trabalhista de Tony Blair, o Fórum Democrático Húngaro e os espanhóis, Partido Socialista (PSOE) e Partido Popular, são claros exemplos desse tipo de organização partidária, assim como o Kuomintang de Taiwan, que está completando sua transformação, extremamente longa, de partido quase leninista para um partido catch-all. Os principais partidos coreanos manifestam muitos aspectos do partido catch-all, embora permaneçam marcadamente regionais em suas bases e identidades eleitorais, o que lhes confere um caráter de partido étnico (ver Jaung, 2000; Kim, 2000).

Deve-se notar que o nosso conceito de partido catch-all começa com os tipos partidários clássicos descritos por Kirchheimer (1966) em alguns aspectos importantes. O primeiro parte da observação de que Kirchheimer não descreve um tipo ideal estável; segundo sua visão, o partido catch-all evolui de um tipo anterior e, portanto, é definido mais pelo que não é do que pelo que é. Especificamente, a definição de Kirchheimer lista várias formas pelas quais um partido pega-tudo evolui do modelo partidário de integração de mass $^{17}$

17. Na formulação clássica de Kirchheimer (1966, p. 190), as características definidoras do partido catch-all compreendem a "redução drástica da bagagem ideológica do partido [...] mais o fortalecimento de grupos de alta liderança, cujas ações e omissões são agora julgadas do ponto de vista de sua contribuição para a eficiência 
anteriormente dominante e, portanto, ainda está na trajetória evolutiva de longo prazo desse tipo de partido $^{18}$. Nosso tipo ideal é um refinamento das características definidoras que não pressupõe que o partido tenha uma "bagagem ideológica”, uma "classe gardée" ou uma base de filiados considerável. Por conseguinte, de nossa conceituação derivam algumas consequências secundárias que não consideramos como componentes necessários para esse modelo. Com uma análise claramente baseada na experiência dos partidos socialistas da Europa Ocidental, Kirchheimer postula, por exemplo, que, quanto mais declinar a importância dos militantes partidários, mais o controle do partido e da indicação de candidatos tenderá a cair nas mãos da alta liderança partidária nacional. A experiência norte-americana dos partidos do tipo catch-all mostra que esse não é um componente essencial do modelo: de fato, o crescente predomínio do meio televisivo, as campanhas

do sistema social como um todo, e não tanto da identificação com os objetivos de sua organização particular [...] a redução da atuação do membro individual, um papel considerado arcaico, que pode obscurecer a imagem do recém-criado partido catch-all [...] a perda de importância da classe gardée, da classe social específica ou da clientela denominacional, em favor do recrutamento de eleitores entre a população como um todo [...] e assegurando o acesso a uma variedade de grupos de interesse". Deve-se notar que todas essas características definidoras referem-se às formas como o partido catch-all evolui a partir do antigo modelo partidário de integração de massa.

18. Deve-se notar que isso também é verdadeiro para o conceito de Koole (1994) de "partido de quadros moderno". Embora seja mais semelhante à nossa definição de partido catch-all, ele também é um retrato dos partidos que ainda estão em movimento, evoluindo a partir de tipos partidários mais clássicos de integração de massa. O partido de quadros moderno é definido por grupos de liderança altamente profissionalizados, baixa proporção membro/eleitor, enfraquecimento ou rompimento de laços com uma classe gardée e um personalismo cada vez maior das campanhas eleitorais, dominadas pelo meio televisivo. Consistentes com nosso modelo catch-all (mas diferente do de Kirchheimer), aponta que a liderança do partido não se tornou dominante a ponto de eliminar a democracia interna, particularmente no que se refere à nomeação de candidatos. Difere do nosso modelo na medida em que seus apelos eleitorais são mais estáveis e focados do que os apelos mais ecléticos e mutáveis do partido catch-all. Portanto, embora Koole não seja suficientemente preciso nesse ponto, seu modelo também pode se aplicar ao que denominamos partidos "programáticos”. Também difere, já que a estrutura organizacional de massa é mantida. Isso, acreditamos, é reflexo do estado transitório dos partidos holandeses estudados por Koole e, portanto, não pode ser uma característica definidora relevante de um tipo ideal de partido político. 
voltadas para o personalismo ou para resultados e a mudança ou enfraquecimento das alianças partidárias com os grupos sociais que tradicionalmente constituíam sua clientela eleitoral foram aspectos que caminharam lado a lado com a disseminação das eleições primárias como principal forma de nomeação de candidatos e com o proporcional declínio dos chefes de partido. Ao atenuarmos o determinismo organizacional inerente ao modelo kirchheimeriano e eliminarmos essa característica redundante, sua aplicação a um conjunto mais amplo de casos reais ganha força, e outras tipologias presentes em literaturas comparadas de partidos são mais facilmente classificadas nessa espécie partidária.

Assim como o tipo catch-all, o partido programático (ver também Wolinetz, 1991, 2002) é um partido moderno, pluralista/tolerante, organizacionalmente enxuto e cuja função principal é o comando de campanhas eleitorais, campanhas essas que geralmente buscam capitalizar reputação pessoal de seus candidatos. Por outro lado, o partido programático está mais próximo do modelo clássico de partido de massa ideológico por três aspectos. Primeiro, tem uma agenda programática ou ideológica muito mais explícita, consistente e coerente do que a do modelo catch-all, e claramente incorpora os apelos ideológicos ou programáticos às suas campanhas eleitorais e sua agenda legislativa e governamental. Caso opere em um sistema eleitoral majoritário, como no Reino Unido, Estados Unidos e México (p. ex., os conservadores de Margaret Thatcher, os republicanos a partir de 1980 e o Partido de Acción Nacional), tem de manter uma capacidade ampla de agregar interesses, embora os apelos que ele lança sejam menos difusos, vagos e ecléticos do que aqueles dos partidos do catch-all. Segundo, busca ganhar o controle do governo (ou um espaço nele) precisamente por meio dessa definição mais nítida de plataforma ou visão partidária. Terceiro, embora sua organização e base social possam, num sistema majoritário, lembrar as do partido catch-all, num sistema marcadamente proporcional, como em Israel, o partido programático tem uma base social mais enxuta e claramente definida, e possivelmente vínculos mais estreitos com organizações afins na sociedade civil. Nesse caso, sua estratégia eleitoral é mobilizar seu eleitorado cativo, ao invés de aumentá-lo por meio da agregação de interesses. Entre outros exemplos de partido programático estão: o Partido Cívico Democrático (ODS) de Vaclav Klaus; o Partido Comunista da Boêmia e Morávia (KSCM) 
e o Partido Social Democrata Tcheco (CSSD), na República Tcheca: a União Democrática da Polônia; o Partido Socialista Húngaro (MSzP); o Partido Cívico Democrático-Jovens Democratas (Fidesz, antigamente a Aliança dos Jovens Democratas) na Hungria; e o Partido Progressista Democrático (DPP) em Taiwan.

O partido eleitoralista em sua forma mais pura é o que chamamos de partido personalista (denominado “partido não partidário” por Ignazi, 1966, p. 522), já que seu único princípio é fornecer uma máquina para o líder ganhar a eleição e exercer o poder. Ele não se origina da estrutura tradicional das elites locais, mas, normalmente, é uma organização criada ou convertida por um líder nacional titular ou aspirante com o propósito exclusivo de promover suas ambições políticas. Seu apelo eleitoral não se baseia em nenhum programa ou ideologia, mas sim no carisma pessoal do líder/candidato, que é retratado como indispensável para a resolução dos problemas ou crises do país. Embora possa lançar mão de redes clientelistas e/ou da ampla distribuição de benefícios particulares aos apoiadores, sua organização é fraca, elementar e oportunista. De fato, pode ser tão efêmero que, mesmo estando a serviço de um presidente eleito, como Alberto Fujimori no Peru, a ponto de mudar de nome e estrutura em toda eleição. Há outros numerosos exemplos no século XX: a Forza Italia de Silvio Berlusconi; o Congresso-I, que, em apoio a Indira Gandhi, derrotou o restante do Partido do Congresso; o Partido Popular Paquistanês, que Benazir Bhutto herdou de seu pai (portanto, com raízes mais profundas do que os demais partidos personalistas); e os veículos partidários criados às pressas e destinados a apoiar as aspirações eleitorais de Hugo Chávez Frías na Venezuela, Fernando Collor de Mello no Brasil e Joseph Estrada nas Filipinas. Um exemplo clássico recente é o Partido Thai Rak da Tailândia, do magnata dos negócios tailandês, Thaksin Shinawatra, cuja personalidade e vasta fortuna pessoal deram a seu partido uma inédita maioria absoluta no parlamento, apesar de ter sido formado apenas alguns meses antes das eleições de novembro do ano 2000. A maioria desses partidos é ou foi pluralista e tolerante em seu modo de atuação, mas isso nem sempre é verdade, como claramente demonstra o comportamento proto-hegemônico de Fujimori no Peru e de Chávez na Venezuela. 


\section{Partidos de movimento social ou movimentalistas}

Finalmente, há um tipo de organização partidária que ocupa os espaços conceituais existentes entre "partido" e "movimento". Os exemplos mais destacados são os verdes da Alemanha e o Partido da Liberdade Austríaco; de qualquer modo, é preciso deixar claro que esse tipo de organização deve ser incluído nessa tipologia abrangente, já que eles lançam candidatos regularmente e têm sido bem-sucedidos em eleger membros ao parlamento e em participar (como na Alemanha em 1999) de uma coalizão governamental nacional e em muitos estados da federação. Atualmente, na Europa Ocidental, os exemplos mais notórios de partidos de movimento se dividem em dois tipos: partidos libertários de esquerda e partidos de extrema-direita pós-industriais. Todavia, esse gênero de tipos partidários deve ser considerado como sendo "de composição aberta”, já que a fluidez de suas características organizacionais se manifesta de maneiras diferentes em outras partes do mundo ou no curso da história. Isso vale especialmente para partidos recémformados, que ainda não firmaram suas práticas (como o Partido Trabalhista britânico do início do século XX e os gaullistas franceses antes de 1958).

Herbert Kitschelt nos apresenta a análise mais bem detalhada da variante "libertária de esquerda" dos partidos de movimento social. O autor os contrasta com os "partidos convencionais" da Europa Ocidental, que visam principalmente alcançar o poder governamental por meio de cargos eletivos; contam com quadros profissionais no partido e uma ampla organização; representam os grupos de interesse econômicos (trabalhistas ou de negócios); e estão preocupados sobretudo com problemas de distribuição de renda (Kitschelt, 1989, p. 62). Por sua vez, os partidos “libertários de esquerda” são essencialmente "pós-materialistas” em sua orientação e modo de atuar. Rejeitam a importância fundamental dos temas econômicos e se caracterizam por "um consenso negativo de que a predominância do mercado e da burocracia deve ser revertida em favor de relações sociais solidárias e instituições participativas" (Kitschelt, 1989, p. 64). De fato, na ausência de um consenso no apoio de uma ideologia ou conjunto de preferências programáticas único e abrangente, tal "consenso negativo" funciona como o mínimo denominador comum compartilhado por uma clientela de outro modo heterogênea, e a 
agenda partidária gira em torno de uma multiplicidade de temas não limitados a uma única arena. Não há barreiras de filiação ao grupo, que é aberto a todos que desejam participar, tornando a base social e a orientação das posturas dos ativistas ainda mais diversas. O forte compromisso de participação direta leva ao enfraquecimento (e até mesmo rejeição) da organização e da liderança centralizadas, e a um modo por vezes caótico de organizar "assembleias" (como bem ilustra o ataque com balões de água dirigido ao ministro do Exterior, Joshka Fischer, no congresso de 1999 dos verdes alemães). Em termos de organização, o partido de movimentalista baseia-se em "redes de apoio informais, carentes de estrutura formal, hierarquia e comando central" (Kitschelt, 1989, p. 66). Finalmente, o partido de movimento libertário de esquerda enfatiza "a representação eleitoral” em detrimento da lógica da competição eleitoral, o que o torna, por vezes, um parceiro de coalizão nada pragmático e tampouco confiável.

Piero Ignazi (1996) apresenta um panorama sucinto do partido de extrema-direita pós-industrial, visto por ele como um tipo diferente de reação contra as condições da sociedade pós-industrial. Como a ponta o autor, lá onde os libertários de esquerda enfatizam a autoafirmação, a não formalidade e o libertarismo como reação à sociedade moderna e às instituições do Estado, os apoiadores da extrema-direita são movidos por sua atomização e alienação na busca por mais ordem, mais tradição, mais identidade e mais segurança, ao mesmo tempo que atacam o Estado por sua intervenção na economia e por suas políticas de bem-estar social (Ignazi, 1996, p. 557). Como seus antecessores fascistas, eles abraçam "o princípio da liderança" e não questionam as diretrizes do líder principal do partido (p. ex., Le Pen, da Frente Nacional, e Haider, do Partido da Liberdade). No entanto, diferem dos fascistas (os quais apoiavam um partido forte, disciplinado e militante como arma a ser utilizada contra os inimigos, especialmente os partidos socialistas e comunistas) por serem hostis ao "partido" e ao "establishment" de forma mais geral. Em vez disso, evidencia-se fortemente uma linha de confronto marcada pela hostilidade xenofóbica e racista em relação aos imigrantes. Ademais, os fascistas pleiteavam a construção de um Estado forte, enquanto para esse tipo de partido uma retórica neoconservadora antiestatista e ataques ao bem-estar social permeiam os discursos e propostas programáticas dos líderes 
e candidatos (ver as diversas contribuições de Betz e Immerfall, $1998)^{19}$.

\section{Quinze espécies de tipos ideais de partido e sua construção teórica}

A tipologia aqui desenvolvida é, sem dúvida, menos parcimoniosa do que os modelos de duas, três ou quatro categorias que dominaram até agora a literatura comparada de partidos políticos. Os acadêmicos que preferem os estilos de construção teórica baseados na dedução a partir de um conjunto unidimensional de critérios podem não receber muito bem essa contribuição, considerando que sua complexidade e multidimensionalidade podem atrapalhar a construção teórica. Pedimos licença para discordar. Acreditamos que as teorias das ciências sociais que pretendem explicar o comportamento humano ou a atuação das instituições devem refletir rigorosamente as condições do mundo real. Como dito anteriormente, julgamos que, em sua maior parte, as tipologias antes dominantes estavam incompletas, na medida em que se baseavam na experiência histórica da Europa Ocidental entre o século XIX e metade do XX. Assim sendo, elas não refletem adequadamente a realidade mais diversa dos partidos políticos de outras partes do mundo: como sugerimos, as profundas clivagens étnicas que dividem muitas sociedades africanas e asiáticas não têm nenhuma correspondência com o contexto étnico, linguístico, religioso e cultural muito mais homogêneo da Europa Ocidental. Portanto, para que uma tipologia de partidos possa ser

19. Pode haver uma tentação de especular que essa diferença fundamental é produto das diferenças de status quo social e político contra os quais o partido reage. $\mathrm{Na}$ década de 1920, o Estado era "enxuto", e a principal ameaça à ordem social vinha dos partidos militantes da esquerda marxista. Na década de 1930, a Depressão fez do clamor por um Estado mais ativo uma resposta razoável ao desemprego e à pobreza generalizada. Nas décadas de 1980 e 1990, no entanto, o Estado do bem-estar social estava plenamente desenvolvido na maioria dos países europeus ocidentais (especialmente na Áustria e na França, onde esses partidos de extrema-direita tiveram grande impacto político). Portanto, o ataque ao Estado intervencionista representava a "reação" óbvia nesse processo dialético de formação ideológica. Além disso, o declínio do marxismo militante e dos partidos classistas de massa juntamente com a migração maciça de países do Terceiro Mundo e da ex-União Soviética para a Europa Ocidental criaram, efetivamente, uma nova minoria a ser detestada por esses partidos xenofóbicos. 
utilizada em análises comparativas mais amplas de diferentes regiões, ela deve admitir a emergência de tipos distintos nos mais variados contextos sociais, como os partidos étnicos, de congresso e fundamentalistas religiosos descritos anteriormente.

Analogamente, não se pode supor que as tipologias baseadas nas características dos partidos da Europa Ocidental dos séculos XIX e XX sejam válidas para todas as épocas, até mesmo dentro dessa própria região. O contexto socioeconômico e as tecnologias de comunicação continuam a evoluir, e têm importantes implicações na estrutura, nos recursos, nos objetivos e nos modos de atuação dos partidos políticos. Assim sendo, a divisão dicotômica entre partidos de quadros e de massa, ou entre partidos de representação individual e partidos de integração social ou total, pode refletir rigorosamente a realidade da Europa Ocidental durante a primeira metade do século XX. Entretanto, na segunda metade desse século, ficou claro que esses modelos partidários clássicos foram se tornando cada vez mais incapazes de dar conta da diversidade de tipos de partido presente nas democracias estáveis. O modelo catch-all de Kirchheimer (1966) certamente ajudou a suprir tal deficiência, ao identificar as formas pelas quais muitos partidos tenderam a desviar-se do modelo de partido de massa. Nas décadas seguintes, no entanto, a classificação de catch-all passou a ser usada para descrever uma variedade excessivamente ampla de partidos cujas estratégias eleitorais e compromissos programáticos diferiam substancialmente. Assim, acreditamos ser necessário desmembrar esse clássico, mas “superagregado" tipo partidário em três diferentes tipos de partido eleitoralista.

O teste de hipóteses e a construção teórica são facilitados por tipos ideais que abarcam todos os elementos definidores de um conceito, mas ao mesmo tempo não "superagregam" por meio da inclusão de elementos que não devem estar juntos nem conceitualmente nem empiricamente. Como Peter Mair (1989) apontou, por exemplo, o modelo catch-all conforme elaborado por Kirchheimer (1966) inclui componentes ideológicos e organizacionais: a desvalorização do compromisso ideológico de um partido está inteiramente ligado à leveza de sua estrutura organizacional e a uma ênfase maior (tanto eleitoral como organizacional) em sua liderança nacional. Como Wolinetz (1991), acreditamos ser necessário separar as dimensões ideológica e organizacional (como fizemos ao elaborar nossos modelos para os partidos catch-all, programático e personalista) tanto 
para refletir a realidade de forma mais acurada, quanto para facilitar a análise das causas das mudanças partidárias.

Consideramos isso desejável, pois a evolução dos partidos ou o surgimento de novos tipos pode ser produto de vários processos causais fundamentalmente distintos, dos quais nem todos conduziriam a transformação no mesmo rumo, e nem todos são unilineares em suas implicações evolutivas. Em relação à dimensão organizacional do partido catch-all clássico, a profecia (o lamento, na verdade) de Kirchheimer a respeito do declínio geral dos partidos de massa e sua substituição ou evolução para o que chamamos de partidos eleitoralistas certamente se tornou fato. Vários estudos empíricos registraram o declínio da filiação partidária (p. ex., Mair e van Biezen, 2001; Scarrow, 2000) e o afrouxamento ou ruptura dos laços que unem os partidos aos meios de comunicação e às organizações auxiliares na maioria dos países da Europa Ocidental (Koole, 1994; van der Eijk, 2000), assim como o surgimento de partidos organizacionalmente enxutos em novas democracias do antigo bloco soviético (p. ex., Kopecký, 1995). De fato, visto que Kirchheimer escreveu em uma época anterior à ascensão da televisão como meio de comunicação predominante nas campanhas ao redor do mundo (Gunther e Mughan, 2000; Pasquino, 2001), ele realmente subestimou o grau em que a política eleitoral seria personalizada e liberada da dependência de uma base de militantes partidários.

Mas o prognóstico de Kirchheimer de que essas mudanças organizacionais seriam acompanhadas pela desvalorização progressiva dos compromissos ideológicos partidários ainda não se cumpriu, ao menos não em países como os Estados Unidos e o Reino Unido. Alguns partidos eleitoralistas, como os conservadores britânicos de Margaret Thatcher e os republicanos dos Estados Unidos em nível nacional ${ }^{20}$ a partir de 1980 adotaram compromissos ideológicos e

20. A tarefa de classificar os partidos norte-americanos de acordo com um único tipo partidário mostra-se cada vez mais difícil, já que as agremiações partidárias dos Estados Unidos são confederações de partidos estaduais (ver Beck, 1997) que podem variar consideravelmente (alguns se aproximando dos modelos catch-all ou programático, enquanto outros ainda mantêm muitos elementos clientelistas). Portanto, ao mesmo tempo em que o Partido Republicano se torna cada vez mais programático no Congresso, muitos governadores estaduais e seus partidos apoiadores permanecem praticantes centralizadores e pragmáticos da política do catch-all. 
formas de confronto muito mais intensos, ao mesmo tempo que dominaram as "novas políticas de campanha eleitoral". Outros, como os socialistas holandeses, percorreram o ciclo completo nas últimas três décadas, mudando para uma postura esquerdista mais radical ao fim da década de 1960 (Wolinetz, 1991, p. 121), para então retornar a uma posição de centro duas décadas depois (Koole, 1994, p. 281). Portanto, para descrever de maneira correta essas tendências de evolução divergentes e tentar explicá-las, é necessário separar a dimensão organizacional das dimensões ideológica ou programática.

Assim, desmembramos os modelos partidários superagregados em tipos teoricamente mais austeros e modestos, a fim de facilitar futuras análises de impactos separadamente dos processos causais distintos que podem mover os partidos em direções diferentes simultaneamente. A maioria das variações nas formas organizacionais dos partidos e nas suas modalidades de campanha pode ser explicada por processos de desenvolvimento socioeconômico de longo prazo (alterando a sociedade na qual as campanhas serão realizadas) e pelos avanços tecnológicos. As mudanças tecnológicas, por exemplo, e especialmente a ascensão da televisão como meio dominante de comunicação política em quase todas as democracias (e, mais recentemente, a internet como forma de "transmissão segmentada ${ }^{21}$ ") abriu canais mais diretos de acesso da elite partidária aos eleitores, tornando desnecessários os meios mais antigos e menos eficientes de mobilização, baseados na campanha porta-à-porta dos militantes (ver Farrell e Webb, 2000). No entanto, se, por um lado, essas transformações socioeconômicas e tecnológicas podem criar circunstâncias favoráveis ao desenvolvimento e ao predomínio progressivo dos partidos organizacionalmente delgados, por outro, não podem prever com exatidão que tipo de partido tem mais probabilidade de emergir, nem qual modelo será predominante. Decisões da elite que buscam diferentes estratégias de mobilização dos eleitores ou objetivos completamente distintos (p. ex., a representação do eleitorado, em lugar da maximização dos votos) podem levar à adoção de uma postura mais nítida em termos ideológicos e programáticos. Essas

21. O termo preciso utilizado pelo autor é: narrowcasting. O termo se construiu em contraposição ao broadcasting atuando com a fidelização de segmentos publicitários em contraposição ao amplo escopo de atuação previsto pelo seu predecessor. N. R. 
últimas decisões provavelmente foram influenciadas, e não meramente determinadas, por fatores socioeconômicos e tecnológicos ${ }^{22}$, e, portanto, não se pode supor que evoluam de maneira unilinear.

As ideologias, as filosofias de representação e, até certo ponto, as formas organizacionais dos partidos provavelmente são afetadas por tendências sociais que podem ter pouco a ver com as mudanças socioeconômicas e tecnológicas. Ao invés de evoluir de maneira unilinear, as características definidoras de algumas subculturas político-partidárias parecem surgir por meio de processos dialéticos de reação contra alguns aspectos do status quo. De fato, é possível levantar hipóteses sobre uma cadeia de mudanças reacionais nas ideologias partidárias cujas origens temporais remontam ao mais antigo período contemplado em nossa pesquisa de partidos políticos: o início do século XIX, quando surgiram, na Europa Ocidental, os partidos de elite de representação individual, que tendiam a ser, ou conservadores tradicionalistas, ou liberais em sua orientação ideológica. Os primeiros defendiam vários aspectos do ancien regime, na época ameaçados pelas mudanças políticas e socioeconômicas, ao passo que o liberalismo clássico surgiu como reação a essa antiga ordem. Uma vez que a ordem pré-democrática tradicional, social e política da Europa Ocidental era caracterizada pelo mercantilismo, a monarquia, a aristocracia privilegiada e as religiões estabelecidas pelo Estado, não é de admirar que o liberalismo clássico enfatizasse o capitalismo de livre-mercado, o individualismo e a liberdade religiosa, ou o anticlericalismo. Na segunda metade do século XIX, foi o capitalismo de livre-mercado que definiu o status quo, com a polarização social entre os economicamente privilegiados e as classes trabalhadoras, o que favoreceu o surgimento dos partidos socialistas e valorizou a solidariedade de classe e a igualdade econômica. Por outro lado, no início do século XX, o confronto entre o capitalismo de livre-mercado e as opções socialistas definiram os parâmetros dos conflitos políticos institucionalizados, levando, como alternativa, à articulação de uma "terceira via" corporativista. Isso fez avançar uma visão de sociedade na qual iriam se basear tanto os partidos denominacionais quanto os ultranacionalistas (exemplos da

22. O aumento da riqueza e o crescimento da classe média, por exemplo, podem minar a credibilidade e a atratividade de ideologias e programas que clamem por mudanças socioeconômicas radicais. 
Europa Ocidental no século XX arraigados em uma visão integral, orgânica e corporativista de sociedade). E, nos estertores do século $\mathrm{XX}$, a prosperidade generalizada, o intervencionismo keynesiano e o enorme Estado do bem-estar social definiram o status quo contra o qual reagiriam ambos os partidos, o libertário de esquerda e o de extrema-direita pós-industriais ${ }^{23}$. Assim, é possível perceber que as características definidoras de importantes ideologias políticas emergiram não como produtos de processos evolutivos unilineares (como processos de modernização socioeconômica contínuos e de longo prazo), mas sim por meio de processos reacionários descontínuos, comandados pelas elites políticas e sociais. Essa interpretação dialética do surgimento dos partidos e das ideologias possivelmente é especulativa, mas representa o tipo de hipótese que pode ser empiricamente testada, utilizando uma diferenciação mais refinada dos partidos políticos, como essa que aqui propomos.

Os partidos políticos não nascem nem evoluem de maneira contínua, unilinear, e também não convergem em um modelo partidário único. Ao contrário, acreditamos que as mudanças das formas organizacionais, das estratégias eleitorais, dos objetivos programáticos e da orientação ideológica dos partidos sejam produtos de múltiplos processos causais - alguns deles relacionados a processos mais amplos e de longo prazo das mudanças sociais ou tecnológicas, e outros envolvendo o comportamento inovador mais improvável das elites políticas e sociais. Se isso for verdade, então, seria um erro depender de um número excessivamente restrito de tipos partidários, o que leva os acadêmicos a tentar encaixar os novos partidos em modelos inapropriados ou a interromper o processo de construção teórica ao concluir, frustrados, que as teorias e modelos existentes simplesmente não se ajustam aos tipos já estabelecidos. Assim, acreditamos que a tipologia aqui apresentada - menos parcimoniosa, porém refletindo mais a verdadeira diversidade dos tipos de partido ao redor do mundo - deva facilitar o teste de numerosas hipóteses sobre as

23. Para um excelente panorama do surgimento dos partidos políticos europeus em consonância com essas tendências ideológicas, ver Von Beyme (1985, p. 29-158). O esquema classificatório de Von Beyme guarda certa semelhança com o nosso, ele se baseia sobretudo nas orientações ideológica e programática dos partidos (ver Ware, 1996, p. 21-49). Portanto, passa ao largo de certas características organizacionais e comportamentais que consideramos particularmente importantes. 
origens, as funções e as trajetórias evolutivas dos partidos políticos nos diferentes contextos sociais, políticos, tecnológicos e culturais.

\section{Agradecimentos}

Este artigo baseou-se num trabalho anterior, publicado como "Types and Functions of Parties", no livro organizado por Larry Diamond e Richard Gunther, Political Parties and Democracy. Agradecemos os comentários e críticas aos primeiros rascunhos deste artigo, feitos por Hans Daalder, Peter Mair, Herbert Kitschelt, Jakub Zielinski, Bradley Richardson e Anthony Mughan.

\section{Referências}

ADORNO, T. W.; FRENKEL-BRUNSWIK, E.; LEVINSON, D. J.; SANFORD, R. N. (1950). The Authoritarian Personality. New York: Harper.

BARNES, S. H. (1967). Party Democracy: Politics in an Italian Socialist Federation. New Haven, CT: Yale University Press.

BECK, P. A. (1997). Party Politics in America. $8^{\text {th }}$ edn. New York: Longman.

BETZ, H.-G.; IMMERFALL, S. (eds.) (1998). The New Politics of the Right: NeoPopulist Parties and Movements in Established Democracies. New York: St. Martin's Press.

BEYME, K. von (1985). Political Parties in Western Democracies. Aldershot: Gower. BOSCO, A. (2001). Four Actors in Search of a Role: The Southern European Communist Parties. In: DIAMANDOUROS, P. N.; GUNTHER, R. (eds.). Parties, Politics and Democracy in the New Southern Europe. Baltimore; London: Johns Hopkins University Press.

BURTON, M.; GUNTHER, R.; HIGLEY, J. (1992). Introduction: Elite Transformations and Democratic Regimes. In: HIGLEY, J.; GUNTHER, R. (eds.). Elites and Democratic Consolidation in Latin America and Southern Europe. Cambridge; New York: Cambridge University Press.

CARR, R. (1966). Spain: 1808-1939. Oxford: Clarendon Press.

CHAMBERS, W. N.; BURNHAM, W. D. (1967). The American Party Systems: States of Political Development. Oxford; New York: Oxford University Press.

DAALDER, H. (2001). The Rise of Parties in Western Democracies. In: DIAMOND, L.; GUNTHER, R. (eds.). Political Parties and Democracy. Baltimore; London: Johns Hopkins University Press.

DALTON, R. J.; WATTENBERG, M. P. (2000). Parties Without Partisans: Political Change in Advanced Industrial Democracies. Oxford: Oxford University Press. 
DIAMOND, L.; GUNTHER, R. (eds.). (2001). Political Parties and Democracy. Baltimore; London: Johns Hopkins University Press.

DUVERGER, M. (1954). Political Parties. London: Methuen.

ELDERSVELD, S. (1964). Political Parties: A Behavioral Analysis. Chicago, IL: Rand-McNally.

EPSTEIN, L. D. (1967). Political Parties in Western Democracies. New York: Praeger. ERIE, S. P. (1988). Rainbow's End: Irish-Americans and the Dilemmas of Urban Machine Politics, 1840-1985. Berkeley, CA: University of California Press.

FARRELL, D. M.; KOLODNY, R.; MEDVIC, S. K. (2000). Political Parties and Campaign Professionals in a Digital Age: Political Consultants in the U.S. and their Counterparts Overseas. Trabalho apresentado no XVII ${ }^{\text {th }}$ World Congress of Political Science, Québec, 1-5 ago.

FARRELL, D. M.; WEBB, P. (2000). Political Parties as Campaign Organizations. In: DALTON, R. J.; WATTENBERG, M. P. (eds.). Parties Without Partisans: Political Change in Advanced Industrial Democracies. Oxford: Oxford University Press.

FOGARTY, M. P. (1957). Christian Democracy in Western Europe, 1820-1953. Notre Dame: University of Notre Dame Press.

GOSNELL, H. F. (1939). Machine Politics: Chicago Style. Chicago, IL: University of Chicago Press.

GUNTHER, R.; MONTERO, J. R.; LINZ, J. J. (eds.) (2002). Political Parties: Old Concepts and New Challenges. Oxford: Oxford University Press.

GUNTHER, R.; MUGHAN, A. (eds.) (2000). Democracy and the Media: A Comparative Perspective. Cambridge; New York: Cambridge University Press.

GUNTHER, R.; SANI, G.; SHABAD, G. (1986). Spain After Franco: The Making of a Competitive Party System. Berkeley, CA: University of California Press.

HAGOPIAN, F. (1996). Traditional Politics and Regime Change in Brazil. Cambridge; New York: Cambridge University Press.

HOROWITZ, D. L. (1985). Ethnic Groups in Conflict. Berkeley, CA: University of California Press.

HUNTINGTON, S. P.; NELSON, J. M. (1976). No Easy Choice: Political Participation in Developing Countries. Cambridge, MA: Harvard University Press.

IGNAZI, P. (1996). The Crisis of Parties and the Rise of New Political Parties. Party Politics, vol. 2, p. 549-566.

JAUNG, H. (2000). Electoral Politics and Political Parties. In: Diamond, L.; SHIN, D. C. (eds.). Institutional Reform and Democratic Consolidation in Korea. Stanford, CA: Hoover Institution.

KALYVAS, S. (1996). The Rise of Christian Democracy in Europe. Ithaca, NY: Cornell University Press.

KATZ, R. S.; MAIR, P. (1992). Party Organization: A Data Handbook. London: Sage. 
KATZ, R. S.; MAIR, P. (eds.) (1994). How Parties Organize: Change and Adaptation in Party Organization in Western Democracies. London; Thousand Oaks: Sage.

KATZ, R. S.; MAIR, P. (1995). Changing Models of Party Organization and Party Democracy. Party Politics, vol. 1, p. 5-28.

KATZ, R. S.; MAIR, P. (2002). The Ascendancy of the Party in Public Office: Party Organizational Change in Twentieth-Century Democracies. In: GUNTHER, R;; Montero, J. R.; Linz, J. J. (eds.). Political Parties: Old Concepts and New Challenges. Oxford: Oxford University Press.

KEY, V. O. (1949). Southern Politics. New York: Vintage.

KIM, B.-K. (2000). Party Politics in South Korea's Democracy: The Crisis of Success. In: DIAMOND, L.; KIM, B.-K. (eds.). Consolidating Democracy in South Korea. Boulder, CO: Lynn Reinner.

KING, A. (1969). Political Parties in Western Democracies: Some Sceptical Reflections. Polity, vol. 2, p. 111-141.

KIRCHHEIMER, O. (1966). The Transformation of the Western European Party Systems. In: LAPALOMBARA, J.; WEINER, M. (eds.). Political Parties and Political Development. Princeton, NJ: Princeton University Press.

KITSCHELT, H. (1989). The Logics of Party Formation. Ithaca, NY: Cornell University Press.

KITSCHELT, H. (1994). The Transformation of European Social Democracy. Cambridge; New York: Cambridge University Press.

KITSCHELT, H. (2001). Divergent Paths of Postcommunist Democracies. In: DIAMOND, L.; GUNTHER, R. (eds.). Political Parties and Democracy. Baltimore, MD: Johns Hopkins University Press.

KOOLE, R. (1994). The Vulnerability of the Modern Cadre Party in the Netherlands'. In: KATZ, R. S.; MAIR, P. (eds.). How Parties Organize: Change and Adaptation in Party Organization in Western Democracies. London; Thousand Oaks: Sage.

KOOLE, R. (1996). Cadre, Catch-all or Cartel? A Comment on the Notion of the Cartel Party. Party Politics, vol. 2, p. 507-523.

KOPECKÝ, P. (1995). Developing Party Organizations in East-Central Europe. Party Politics, vol. 1, p. 515-534.

LAPALOMBARA, J.; WEINER, M. (1966). The Origin and Development of Political Parties. In: LAPALOMBARA, J.; WEINER, M. (eds.). Political Parties and Political Development. Princeton, NJ: Princeton University Press.

LINZ, J. J. (1978). The Breakdown of Democratic Regimes: Crisis, Breakdown and Reequilibration. Baltimore; London: Johns Hopkins University Press.

MAINWARING, S.; SCULLY, T. R. (eds.). (1995). Building Democratic Institutions: Party Systems in Latin America. Stanford, CA: Stanford University Press. 
MAIR, P. (1989). Continuity, Change and the Vulnerability of Party. West European Politics, vol. 12, p. 169-187.

MAIR, P. (1994). Party Organizations: From Civil Society to the State. In: KATZ, R. S.; MAIR, P. (eds.). How Parties Organize: Change and Adaptation in Party Organization in Western Democracies. London; Thousand Oaks: Sage.

MAIR, P.; Biezen, I. van (2001). Party Membership in Twenty European Democracies, 1980-2000. Party Politics, vol. 7, p. 5-21.

MARTÍNEZ CUADRADO, M. (1969). Elecciones y partidos políticos de España (1868-1931). Madrid: Taurus.

MICHELS, R. (1915). Political Parties: A Sociological Study of the Oligarchical Tendencies of Modern Democracy. New York: Hearst's International Library.

NEUMANN, S. (1956). Towards a Comparative Study of Political Parties. In: NEUMANN, S. (ed.). Modern Political Parties. Chicago, IL: University of Chicago Press.

ORLOW, D. (1973). The History of the Nazi Party. Pittsburgh, PA: University of Pittsburgh Press. Vol. 2.

PANEBIANCO, A. (1988). Political Parties: Organization and Power. Cambridge; New York: Cambridge University Press.

PASQUINO, G. (2001). The New Campaign Politics in Southern Europe. In: DIAMANDOUROS, P. N.; Gunther, R. (eds.). Parties, Politics and Democracy in the New Southern Europe. Baltimore; London: Johns Hopkins University Press.

PUHLE, H.-J. (2002). Still the Age of Catch-allism? Volksparteien and Parteienstaat in Crisis and Reequilibration. In: GUNTHER, R.; MONTERO, J. R.; LINZ, J. J. (eds.). Political Parties: Old Concepts and New Challenges. Oxford: Oxford University Press.

SCARROW, S. E. (2000). Parties Without Members? Party Organization in a Changing Electoral Environment. In: DALTON, R. J.; WATTENBERG, M. P. (eds.). Parties Without Partisans: Political Change in Advanced Industrial Democracies. Oxford: Oxford University Press.

SCHMIDT, C. T. (1939). The Corporate State in Action. London: Victor Gollanz.

SCHURMANN, F. (1966). Ideology and Organization in Communist China. Berkeley, CA: University of California Press.

TUSELL, J. (1976). Oligarquía y caciquismo en Andalucía. 1890-1923. Barcelona: Planeta.

VAN DER EIJK, C. (2000). The Netherlands: Media and Politics between Segmented Pluralism and Market Forces. In: GUNTHER, R.; MUGHAN, A. (eds.). Democracy and the Media: A Comparative Perspective. New York; Cambridge: Cambridge University Press. 
WARE, A. (1996). Political Parties and Party Systems. Oxford; New York: Oxford University Press.

WEAVER, R. K.; ROCKMAN, B. A. (1993). 'When and How Do Institutions Matter? In: WEAVER, R. K.; ROCKMAN, B. A. (eds.). Do Institutions Matter? Government Capabilities in the United States and Abroad. Washington: Brookings Institution.

WOLINETZ, S. (1991). Party System Change: The Catch-all Thesis Revisited. West European Politics, vol. 14, p. 113-128.

WOLINETZ, S. (2002). Beyond the Catch-all Party: Approaches to the Study of Parties and Party Organization. In: Gunther, R.; Montero, J. R.; Linz, J. J. (eds.). Political Parties: Old Concepts and New Challenges. Oxford: Oxford University Press. 
